Article

\title{
Novel Homo-Bivalent and Polyvalent Compounds Based on Ligustrazine and Heterocyclic Ring as Anticancer Agents
}

\author{
Jiawen Wang ${ }^{1,+}$, Ge Hong ${ }^{2,3,+}$, Guoliang Li ${ }^{2}$, Wenzhi Wang ${ }^{2}$ and Tianjun Liu $1,2,3, *$ \\ 1 Graduate Institute, Tianjin University of Traditional Chinese Medicine, Tianjin 301617, China; \\ m13260192393@163.com \\ 2 Tianjin Key Laboratory of Biomedical Materials, Institute of Biomedical Engineering, Chinese Academy of \\ Medical Sciences \& Peking Union Medical College, Tianjin 300192, China; hongge6688@aliyun.com (G.H.); \\ liguoliangsx@163.com (G.L.); wxwnx123@163.com (W.W.) \\ 3 State Key Laboratory of Bioactive Substances and Functions of Natural Medicines, Institute of Materia \\ Medica, Chinese Academy of Medical Sciences and Peking Union Medical College, Beijing 100050, China \\ * Correspondence: Liutj@bme.org.cn \\ $\dagger$ These authors contributed equally to this work.
}

Academic Editor: Qiao-Hong Chen

Received: 7 November 2019; Accepted: 6 December 2019; Published: 9 December 2019

\begin{abstract}
Bivalent and polyvalent inhibitors can be used as antitumor agents. In this experiment, eight ligustrazine dimers and seven ligustrazine tetramers linked by alkane diamine with different lengths of carbon chain lengths were synthesized. After screening their antiproliferation activities against five cancer cell lines, most ligustrazine derivatives showed better cytotoxicity than the ligustrazine monomer. In particular, ligustrazine dimer 8e linked with decane-1,10-diamine exhibited the highest cytotoxicity in FaDu cells with an $\mathrm{IC}_{50}$ (50\% inhibiting concentration) value of $1.36 \mathrm{nM}$. Further mechanism studies suggested that $8 \mathbf{e}$ could induce apoptosis of $\mathrm{FaDu}$ cells through the depolarization of mitochondrial membrane potential and S-phase cell cycle arrest. Inspired by these results, twenty-seven additional small molecule heterocyclic dimers linked with decane-1,10-diamine and nine cinnamic acid dimers bearing ether chain were synthesized and screened. Most monocyclic and bicyclic aromatic systems showed highly selective anti-proliferation activity to FaDu cells and low toxicity to normal MCF 10A cells. The structure-activity relationship revealed that the two terminal amide bonds and the alkyl linker with a chain length of 8-12 carbon were two important factors to maintain its antitumor activity. In addition, the ADMET calculation predicted that most of the potent compounds had good oral bioavailability.
\end{abstract}

Keywords: bivalency; polyvalency; antitumor; apoptosis; cell cycle

\section{Introduction}

Natural products play a vital role in the development of the drug, especially anticancer drugs [1]. Ligustrazine (2,3,5,6-tetramethylpyrazine, TMP), an important component of the Chinese traditional medicinal herb Chuanxiong (Ligusticum chuanxiong Hort), has been of wide clinical use for cardiovascular and cerebrovascular diseases [2]. Recently, TMP has been reported to possess anticancer activity in vitro and in vivo, inducing cancer cell apoptosis and cell cycle modulation [3,4]. More importantly, the introduction of different substituted groups into ligustrazine has helped to improve the antitumor activity. Many ligustrazine derivatives with potent antitumor activity have been developed in the past few years, like monocarbonyl ligustrazine-curcumin hybrids [5], ligustrazine-betulinic acid hybrids [6], and ligustrazine-rhein derivatives [7]. This advancement stimulated our interest in using TMP as the scaffold to synthesize new antitumor agents. 
In the interaction between host and guest molecules, both bivalency and polyvalency could enhance the affinity and activity of monovalent ligand [8,9]. This phenomenon has attracted attention in drug design. Many effective bivalent anti-cancer drugs have been found, such as artemisinin-derivative dimers [10], jesterone dimer [11], indole-3-carbinol dimer [12], bis-daunorubicin [13]. Previous work in this field has designed and synthesized several ligustrazine dimers linked by cyclohexanone and oxime [14], curcumin [15], or triterpenes [16], which had a good cytotoxic effect on human cancer cells. The result showed that the dimerization of ligustrazine could obviously improve the antitumor potency of its monomer.

With an effort to developing new antitumor agents, we designed and synthesized a series of novel TMP dimers and tetramers linked with different alkyl diamines and screened their anti-proliferation potential on a panel of human cancer cell lines, including HeLa, Hep G2, MCF-7, FaDu, and A549. Based on these experimental results, according to the importance of small molecular heterocyclic rings in drug discovery [17], additional dimers series of aromatic rings instead of ligustrazine, a total of 51 new compounds were synthesized, screened, and their structure-activity relationship was briefly discussed. Meanwhile, through morphological observation and flow cytometric analysis, the antitumor mechanisms of the most potent one were preliminarily discussed in this study. ADMET properties of all compounds were also evaluated to explore the drug-likeness.

\section{Results and Discussion}

\subsection{Chemistry}

In this study, 51 novel designed compounds were synthesized. Series $\mathbf{6 a}-\mathbf{g}$ and $\mathbf{8 a}-\mathbf{f}$ were obtained according to the synthetic method described in Schemes 1 and 2. The important intermediate 2-chloromethyl-3,5,6-trimethyl-pyrazine 5 was prepared from ligustrazine by the tandem reaction: Boekelheide reaction [18] and deprotection and the chlorination reaction [19]. The key intermediate 2-carboxylic acid-3,5,6-trimethyl-pyrazine 7 was synthesized by the one-pot reaction, as previously reported [20]. To explore the length effect, the TMP moieties, with 2-12 methylene alkyl chain as a linker, were synthesized.

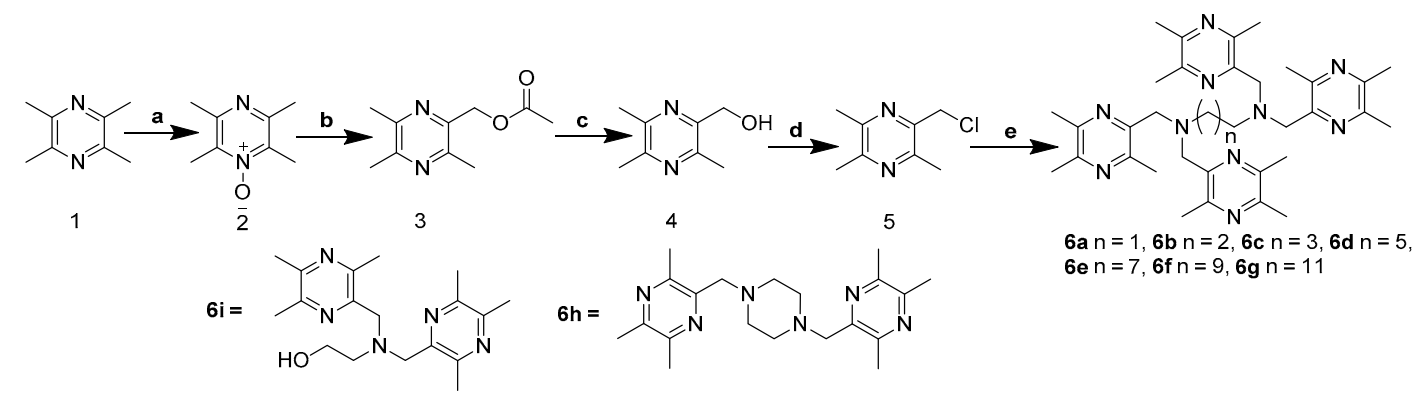

Scheme 1. Synthesis of the TMP complexes 6a-6i. Reagents and conditions: (a) $30 \% \mathrm{H}_{2} \mathrm{O}_{2}, \mathrm{CH}_{3} \mathrm{COOH}$, $95^{\circ} \mathrm{C}, 2 \mathrm{~h}$; (b) $\left(\mathrm{CH}_{3} \mathrm{CO}\right)_{2} \mathrm{O}, 140{ }^{\circ} \mathrm{C}, 2.5$ h; (c) $\mathrm{CH}_{3} \mathrm{ONa}, \mathrm{CH}_{3} \mathrm{OH}$, r.t., 0.5 h; (d) $\mathrm{SOCl}_{2}, \mathrm{CH}_{2} \mathrm{Cl}_{2}$, r.t., 2.5 h; (e) n-diaminoalkane (piperazine and monoethanolamine), $\mathrm{K}_{2} \mathrm{CO}_{3}, \mathrm{CH}_{3} \mathrm{CN}, 95^{\circ} \mathrm{C}, 2 \mathrm{~h}$.

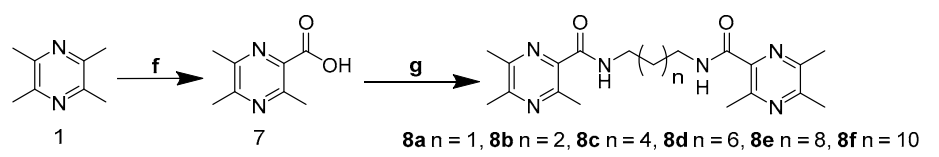

Scheme 2. Synthesis of the Bis-TMP hybrids 8a-8f. Reagents and conditions: (f) $\mathrm{KMnO}_{4}, \mathrm{H}_{2} \mathrm{O}, 37^{\circ} \mathrm{C}, 24$ h; (g) n-diamino-alkane, EDCI/DMAP, r.t., 12 h.

Using heteroaromatic acids with decane-1,10-diamine as raw materials, the target compounds 9e-35e (outlined in Scheme 3) linked by amide chain were synthesized with EDCI (1-(3-Dimethylaminopropyl)-3-ethylcarbodiimide hydrochloride) and DMAP 
(4-Dimethylaminopyridine) in anhydrous $\mathrm{CH}_{2} \mathrm{Cl}_{2}$ at room temperature. Series $\mathbf{9 d}, \mathbf{9} \mathbf{\mathbf { f }} \mathbf{- 1}$ (shown in Scheme 4) linked by ether chain or amide chain were synthesized by the above method. All the newly synthesized compounds were characterized by ${ }^{1} \mathrm{H}-\mathrm{NMR},{ }^{13} \mathrm{C}-\mathrm{NMR}$, and high-resolution mass spectra (HRMS). Details were provided in the experimental part. The purity of the compounds was over $95 \%$ measured by HPLC (Figure 1).

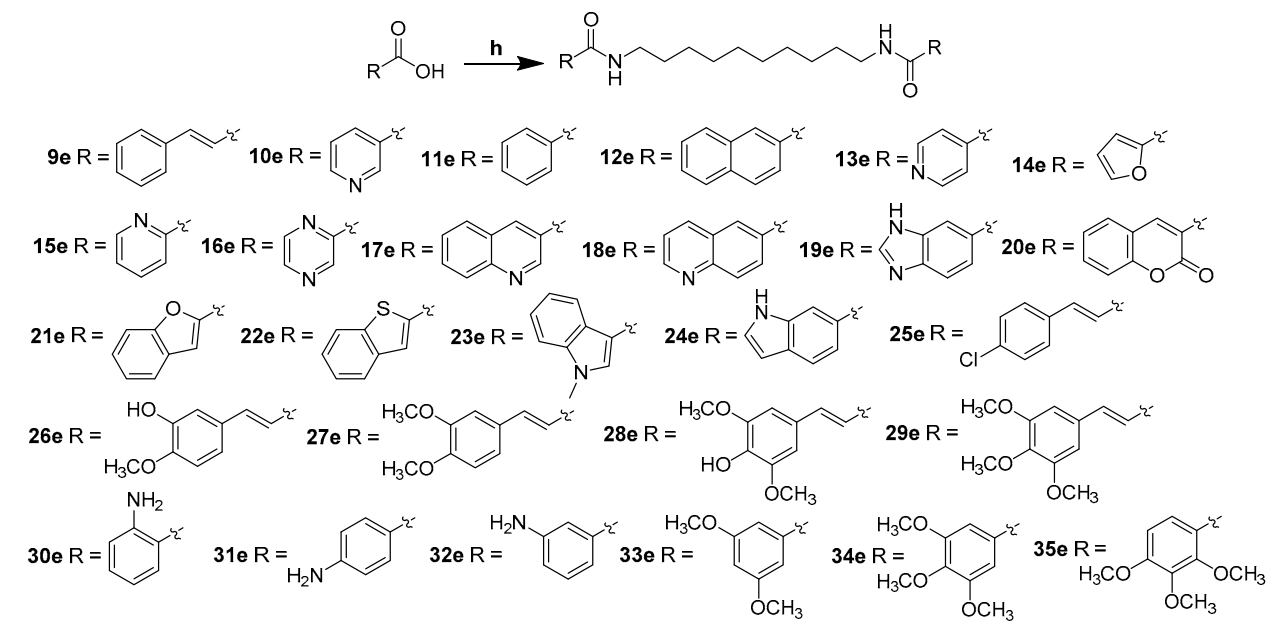

Scheme 3. Synthesis of compounds 9e-35e. Reagents and conditions: (h) decane-1,10-diamine, EDCI/DMAP, r.t., 12 h.

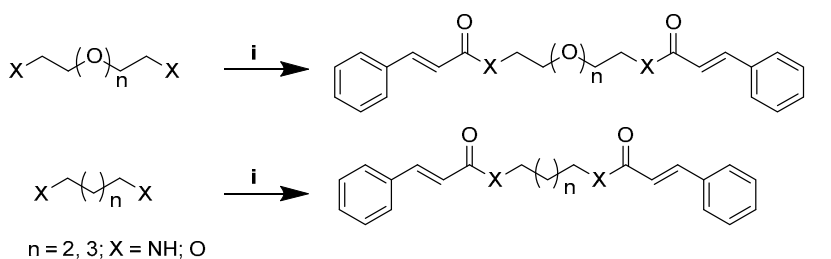
9j $n=2, X=N H ; 9 k n=3, X=N H$
9l $n=2, X=O ; 9 m n=3, X=O$

9d $\mathrm{n}=6, \mathrm{X}=\mathrm{NH} ; \mathbf{9 f} \mathrm{n}=10, \mathrm{X}=\mathrm{NH}$ $9 \mathrm{gn}=6, \mathrm{X}=0 ; 9 \mathrm{~h} \mathrm{n}=8, \mathrm{X}=0$ $9 \mathrm{in}=10, \mathrm{X}=0$

Scheme 4. Synthesis of compounds $9 \mathrm{~d}, \mathbf{9 f}-\mathbf{9 m}$. Reagents and conditions: (i) cinnamic acid, EDCI/DMAP, r.t., $12 \mathrm{~h}$.

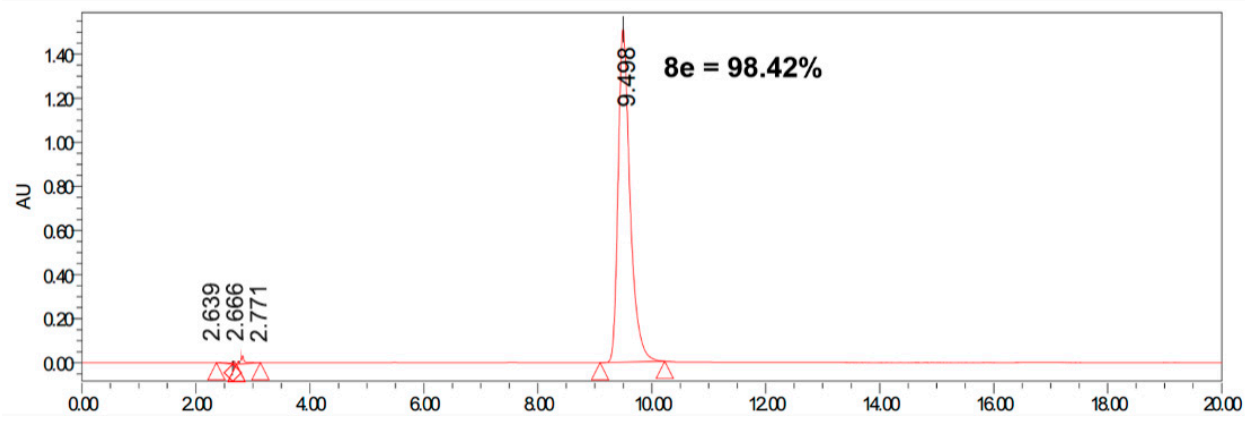

Figure 1. The purity of compound $\mathbf{8 e}$ as a representative analyzed by HPLC (Kromasil C18 column, eluted by methanol/water (80/20) containing $0.1 \%$ trifluoroacetic acid at a flow rate of $1 \mathrm{~mL} / \mathrm{min}$ ).

\subsection{Anti-Proliferative Activity In Vitro}

For the newly synthesized compounds, their anti-proliferative activity on human cancer cell lines, HeLa (cervical carcinoma), Hep G2 (hepatoma carcinoma), MCF-7 (breast carcinoma), FaDu (head and neck carcinoma), A549 (lung carcinoma), and normal mammary epithelial cell line MCF 10A, was screened by MTT assay [21] with doxorubicin (DOX) as the positive control. The $\mathrm{IC}_{50}$ values of these compounds are summarized in Table 1 . Among the ligustrazine derivatives, $\mathbf{6 a}-\mathbf{g}$ and $8 \mathbf{a}-\mathbf{f}$, the tetramers $\mathbf{6 f}$ and $\mathbf{6 g}$ had broad-spectrum cytotoxic activities in all cell lines $\left(\mathrm{IC}_{50}\right.$ 
6.57-20.83 $\mu \mathrm{M}$ ), and the cytotoxicity activities increased with the increase of carbon chain length. The dimeric ligustrazine $\mathbf{8 d} \mathbf{8} \mathbf{8}, \mathbf{8 f}$ showed the most promising anticancer activity in most tested tumor cell lines with $\mathrm{IC}_{50}$ values between 0.00136 and $6.35 \mu \mathrm{M}$, a much better result than DOX and TMP. In particular, compound 8e, two ligustrazine rings linked with decane-1,10-diamine, exhibited the best anti-proliferative ability in cells (except Hep G2), and compared with other linkers, its $\mathrm{IC}_{50}$ values were $1.42 \pm 0.71 \mu \mathrm{M}, 0.037 \pm 0.001 \mu \mathrm{M}, 0.00136 \pm 0.00035 \mu \mathrm{M}, 1.05 \pm 0.05 \mu \mathrm{M}$, and $0.047 \pm 0.008 \mu \mathrm{M}$ against HeLa, MCF-7, FaDu, A549, and MCF 10A, respectively. In light of these results, we replaced TMP with aromatic heterocycles similar to ligustrazine in electronic space. The novel small aromatic molecule and heterocyclic dimers 9e-35e were synthesized, and their anti-proliferative ability was evaluated. Compounds 9e, 10e, 11e, 17e, 18e, 21e, 22e, 23e, and 25e, aromatic acid dimers (cinnamoyl, nicotinoyl, benzoyl, quinoline-3-carboxyl, quinoline-6-carboxyl, benzofuran-2-carboxyl, benzothiophene-2-carboxyl, indol-3-carboxyl, chlorinated cinnamoyl), were linked by decane-1,10-diamine, which had potent anti-proliferative ability in FaDu or A549 cell lines. Their $\mathrm{IC}_{50}$ in $\mathrm{FaDu}$ cell lines were less than $1 \mu \mathrm{M}$, in the range of $20 \mathrm{nM}$ (benzothiophene-2-carboxyl) and $697 \mathrm{nM}$ (benzofuran-2-carboxyl). Also, they had nearly no toxicity in normal cells like MCF 10A. In series $\mathbf{9 d}-\mathbf{n}$, compounds $\mathbf{9 d}-\mathbf{f}\left(\mathrm{IC}_{50}<1 \mu \mathrm{M}\right)$, two cinnamic acids linked by $\mathrm{C} 8, \mathrm{C} 10, \mathrm{C} 12$ chain with two terminal amide bonds, were more effective than compounds $9 \mathrm{~g}-\mathbf{i}\left(\mathrm{IC}_{50}>20 \mu \mathrm{M}\right)$, two cinnamic acids linked by the same alkyl chain with two terminal ester bonds instead of amide bonds. This demonstrated the vital role of two-terminal amide bonds in antitumor activity. Compared with compounds $\mathbf{9 d}-\mathbf{f}$, the inhibition of compounds $\mathbf{9 j}-\mathbf{m}$, two cinnamic acids linked by the similar length ether chain instead of alky chain, was weaker in tumor cells ( $\left.\mathrm{IC}_{50}>20 \mu \mathrm{M}\right)$, which confirmed that the alkyl chain played an important role in the structure. Then, we evaluated the position effect of the substitution at the ortho, meta, or para positions of the same aromatic ring. Compounds 25-35e and the unsubstituted compounds $9 \mathbf{e}$ and 11e were all derivatives of cinnamic acid or benzoic acid with different substituents and electronic effects. The results of the compounds 26-27e or 28-29e confirmed that the substituents had a general effect on the activity, $-\mathrm{OH},-\mathrm{OCH}_{3},-\mathrm{NH}_{2}$, and other electron donor groups could significantly reduce the activity, with the influence of $-\mathrm{OH}$ greater than that of $-\mathrm{OCH}_{3}$. However, the electron attraction group like $-\mathrm{Cl}(\mathbf{2 5 e})$ had no obvious effect. The compounds with para-substituted analogs (31e, para position, $\left.\mathrm{IC}_{50}=5.594 \mu \mathrm{M}\right)$ exhibited better cell growth inhibitory activities in FaDu cells than ortho- and meta- substituted analogs (30e, 32e, ortho and meta position, $\left.\mathrm{IC}_{50}>20 \mu \mathrm{M}\right)$. It is worth noting that para $-\mathrm{OCH}_{3}$ substitution could enhance anticancer activity. The $\mathrm{IC}_{50}$ value of compound $34 \mathrm{e}$ was $5.853 \pm 0.408 \mu \mathrm{M}$, the $\mathrm{IC}_{50}$ value of para- $\mathrm{OCH}_{3}$ was half that of the parent compound $33 \mathbf{e}$, and the $\mathrm{IC}_{50}$ value of compound $33 \mathbf{e}$ was $10.393 \pm 0.949 \mu \mathrm{M}$. Generally, there were three crucial elements in the structure-activity relationship of these systems: alkyl chain linker, two-terminal amide bonds, and heteroaromatic substituents. This SAR (structure-activity relationship) study would help to discover more effective compounds in the future.

To study the selective antiproliferative activities of bivalent and polyvalent inhibitors in normal cells and cancer cell lines, the cytotoxicity of compounds in FaDu cells and normal mammary epithelial MCF 10A cells was measured. The results listed in Table 1 showed that although the ligustrazine dimers $\mathbf{8 d}$ and $\mathbf{8 e}$ had high cytotoxicity in MCF $10 \mathrm{~A}$, their $\mathrm{IC}_{50}$ values were $2.69 \pm 0.46$ and 0.047 $\pm 0.008 \mu \mathrm{M}$, while the $\mathrm{IC}_{50}$ values in FaDu cells were $110 \pm 30$ and $1.36 \pm 0.035 \mathrm{nM}$, respectively, which were far lower than that in MCF 10A. The selective index (SI) between MCF10A and Fadu $\left(\mathrm{IC}_{50}{ }^{\mathrm{MCF} 10 \mathrm{~A}} / \mathrm{IC}_{50}{ }^{\mathrm{FaDu}}\right)$ was 24.45 and 34.56 , respectively. In addition, the heteroaromatic acid dimers 9e-12e, 21e-23e, and 25e had the similar activity, which was stronger than doxorubicin in FaDu cells, and had high selectivity in FaDu cells and MCF $10 \mathrm{~A}$ cells with $\mathrm{SI}\left(\mathrm{IC}_{50}{ }^{\mathrm{MCF}} 10 \mathrm{~A} / \mathrm{IC}_{50}{ }^{\mathrm{FaDu}}\right)$ values over 28.69. In contrast, the $\mathrm{SI}\left(\mathrm{IC}_{50} \mathrm{MCF} 10 \mathrm{~A} / \mathrm{IC}_{50} \mathrm{FaDu}\right)$ value of doxorubicin was 0.43 . These results encouraged us to further investigate the possible cellular mechanisms. 
Table 1. Inhibitory effects of synthetic compounds on the growth of different types of human cancer cells and normal mammary epithelial cells.

\begin{tabular}{|c|c|c|c|c|c|c|c|}
\hline \multirow{2}{*}{ Comp. } & \multicolumn{6}{|c|}{ Antiproliferative Activity $\mathrm{IC}_{50} \pm \mathrm{SEM}(\mu \mathrm{M})$} & \multirow[b]{2}{*}{ SI $[g]$} \\
\hline & HeLa[a] & Hep G2[b] & MCF-7[c] & $\mathrm{FaDu}[\mathrm{d}]$ & A549[e] & MCF 10A[f] & \\
\hline $6 a$ & $>100$ & $>100$ & $>100$ & $>100$ & $>100$ & $90.29 \pm 3.41$ & $\mathrm{NC}^{\mathrm{h}}$ \\
\hline $6 b$ & $>100$ & $>100$ & $>100$ & $>100$ & $>100$ & $>100$ & $\mathrm{NC}^{\mathrm{h}}$ \\
\hline $6 c$ & $>100$ & $>100$ & $>100$ & $>100$ & $>100$ & $>100$ & $N C^{h}$ \\
\hline $6 d$ & $>100$ & $>100$ & $>100$ & $>100$ & $>100$ & $>100$ & $\mathrm{NC}^{\mathrm{h}}$ \\
\hline $6 e$ & $62.67 \pm 4.19$ & $50.77 \pm 1.35$ & $66.36 \pm 0.05$ & $49.50 \pm 1.61$ & $>100$ & $85.44 \pm 2.28$ & 1.73 \\
\hline $6 f$ & $10.16 \pm 0.55$ & $10.72 \pm 0.22$ & $20.83 \pm 0.14$ & $10.94 \pm 0.12$ & $20.05 \pm 0.41$ & $12.97 \pm 0.55$ & 1.19 \\
\hline $6 \mathrm{~g}$ & $7.89 \pm 0.86$ & $9.62 \pm 0.11$ & $9.83 \pm 0.17$ & $6.80 \pm 0.05$ & $9.23 \pm 0.16$ & $6.57 \pm 0.30$ & 0.97 \\
\hline $6 h$ & $>100$ & $>100$ & $>100$ & $>100$ & $>100$ & $>100$ & $\mathrm{NC}^{\mathrm{h}}$ \\
\hline $6 i$ & $>100$ & $>100$ & $>100$ & $>100$ & $>100$ & $>100$ & $\mathrm{NC}^{\mathrm{h}}$ \\
\hline $8 a$ & $>100$ & $>100$ & $>100$ & $>100$ & $>100$ & $>100$ & $\mathrm{NC}^{\mathrm{h}}$ \\
\hline $8 b$ & $>100$ & $>100$ & $>100$ & $>100$ & $>100$ & $>100$ & $\mathrm{NC}^{\mathrm{h}}$ \\
\hline $8 c$ & $>100$ & $>100$ & $>100$ & $80.41 \pm 1.36$ & $>100$ & $46.59 \pm 0.65$ & $\mathrm{NC}^{\mathrm{h}}$ \\
\hline $8 d$ & $3.31 \pm 0.14$ & $>20$ & $0.480 \pm 0.003$ & $0.11 \pm 0.03$ & $6.35 \pm 0.05$ & $2.69 \pm 0.46$ & 24.45 \\
\hline $8 e$ & $1.42 \pm 0.71$ & $>20$ & $0.037 \pm 0.001$ & $0.00136 \pm 0.00035$ & $1.05 \pm 0.05$ & $0.047 \pm 0.008$ & 34.56 \\
\hline $8 f$ & $4.96 \pm 1.62$ & $>20$ & $0.158 \pm 0.009$ & $0.174 \pm 0.010$ & $2.46 \pm 0.05$ & $0.051 \pm 0.021$ & 0.29 \\
\hline $9 e$ & $>100$ & $>100$ & $>100$ & $0.054 \pm 0.002$ & $11.27 \pm 0.81$ & $>100$ & $>1851.85$ \\
\hline $10 \mathrm{e}$ & $>100$ & $>100$ & $>100$ & $0.25 \pm 0.02$ & $2.94 \pm 0.25$ & $38.60 \pm 2.48$ & 154.40 \\
\hline $11 \mathrm{e}$ & $>100$ & $>100$ & $>100$ & $0.50 \pm 0.06$ & $64.30 \pm 3.46$ & $80.54 \pm 7.60$ & 161.08 \\
\hline $12 e$ & $>100$ & $>100$ & $>100$ & $1.33 \pm 0.07$ & $8.77 \pm 0.47$ & $>100$ & $>75.19$ \\
\hline $13 e$ & $>100$ & $>100$ & $>100$ & $48.31 \pm 3.17$ & $>100$ & $>100$ & $>2.07$ \\
\hline $14 \mathrm{e}$ & $>100$ & $97.75 \pm 1.55$ & $>100$ & $6.33 \pm 0.65$ & $44.37 \pm 0.29$ & $19.82 \pm 1.41$ & 3.13 \\
\hline $15 e$ & $37.74 \pm 4.32$ & $26.34 \pm 5.36$ & $21.48 \pm 1.47$ & $8.85 \pm 0.45$ & $23.08 \pm 0.12$ & $54.65 \pm 5.92$ & 6.18 \\
\hline $16 e$ & $>100$ & $>100$ & $>100$ & $88.11 \pm 1.37$ & $>100$ & $>100$ & $\mathrm{NC}^{\mathrm{h}}$ \\
\hline $17 \mathrm{e}$ & $>20$ & $>20$ & $>20$ & $0.236 \pm 0.005$ & $>20$ & $>20$ & $>84.75$ \\
\hline $18 \mathrm{e}$ & $>20$ & $>20$ & $>20$ & $0.697 \pm 0.021$ & $>20$ & $>20$ & $>28.69$ \\
\hline $19 e$ & $>20$ & $>20$ & $>20$ & $8.74 \pm 0.44$ & $>20$ & $>20$ & $>2.29$ \\
\hline $20 \mathrm{e}$ & $>20$ & $>20$ & $>20$ & $>20$ & $>20$ & $>20$ & $\mathrm{NC}^{\mathrm{h}}$ \\
\hline $21 \mathrm{e}$ & $>20$ & $>20$ & $>20$ & $0.665 \pm 0.028$ & $>20$ & $>20$ & $>30.08$ \\
\hline $22 e$ & $>20$ & $>20$ & $>20$ & $0.020 \pm 0.002$ & $>20$ & $>20$ & $>1000$ \\
\hline $23 \mathrm{e}$ & $>20$ & $>20$ & $>20$ & $0.638 \pm 0.089$ & $>20$ & $>20$ & $>31.35$ \\
\hline $24 \mathrm{e}$ & $>20$ & $>20$ & $>20$ & $5.296 \pm 0.366$ & $>20$ & $>20$ & $>3.78$ \\
\hline $25 e$ & $>20$ & $>20$ & $>20$ & $0.056 \pm 0.016$ & $>20$ & $>20$ & $>357.14$ \\
\hline $26 e$ & $>20$ & $>20$ & $>20$ & $>20$ & $>20$ & $>20$ & $\mathrm{NC}^{\mathrm{h}}$ \\
\hline $27 e$ & $>20$ & $>20$ & $>20$ & $4.621 \pm 0.539$ & $>20$ & $>20$ & $>4.33$ \\
\hline $28 \mathrm{e}$ & $>20$ & $>20$ & $>20$ & $>20$ & $>20$ & $>20$ & $\mathrm{NC}^{\mathrm{h}}$ \\
\hline $29 e$ & $>20$ & $>20$ & $>20$ & $5.067 \pm 0.461$ & $>20$ & $>20$ & $>3.95$ \\
\hline $30 \mathrm{e}$ & $>20$ & $>20$ & $>20$ & $>20$ & $>20$ & $>20$ & $\mathrm{NC}^{\mathrm{h}}$ \\
\hline $31 e$ & $>20$ & $>20$ & $>20$ & $5.594 \pm 0.628$ & $>20$ & $>20$ & $>3.58$ \\
\hline $32 e$ & $>20$ & $>20$ & $>20$ & $>20$ & $>20$ & $>20$ & $\mathrm{NC}^{\mathrm{h}}$ \\
\hline $33 e$ & $>20$ & $>20$ & $>20$ & $10.393 \pm 0.949$ & $>20$ & $>20$ & $>1.92$ \\
\hline $34 \mathrm{e}$ & $>20$ & $>20$ & $>20$ & $5.853 \pm 0.408$ & $>20$ & $>20$ & $>3.42$ \\
\hline $35 \mathrm{e}$ & $>20$ & $>20$ & $>20$ & $>20$ & $>20$ & $>20$ & $\mathrm{NC}^{\mathrm{h}}$ \\
\hline $9 d$ & $>20$ & $>20$ & $>20$ & $1.054 \pm 0.091$ & $>20$ & $>20$ & $>18.98$ \\
\hline $9 f$ & $>20$ & $>20$ & $>20$ & $0.027 \pm 0.002$ & $>20$ & $>20$ & $>740.74$ \\
\hline $9 \mathrm{~g}$ & $>20$ & $>20$ & $>20$ & $>20$ & $>20$ & $>20$ & $\mathrm{NC}^{\mathrm{h}}$ \\
\hline $9 \mathrm{~h}$ & $>20$ & $>20$ & $>20$ & $>20$ & $>20$ & $>20$ & $\mathrm{NC}^{\mathrm{h}}$ \\
\hline $9 \mathrm{i}$ & $>20$ & $>20$ & $>20$ & $>20$ & $>20$ & $>20$ & $\mathrm{NC}^{\mathrm{h}}$ \\
\hline $9 j$ & $>20$ & $>20$ & $>20$ & $>20$ & $>20$ & $>20$ & $N C^{h}$ \\
\hline $9 \mathrm{k}$ & $>20$ & $>20$ & $>20$ & $4.447 \pm 0.208$ & $>20$ & $>20$ & $>4.50$ \\
\hline 91 & $>20$ & $>20$ & $>20$ & $>20$ & $>20$ & $>20$ & $N C^{h}$ \\
\hline $9 m$ & $>20$ & $>20$ & $>20$ & $>20$ & $>20$ & $>20$ & $\mathrm{NC}^{\mathrm{h}}$ \\
\hline TMP & $>100$ & $>100$ & $>100$ & $>100$ & $>100$ & $>100$ & $\mathrm{NC}^{\mathrm{h}}$ \\
\hline DOX & $11.39 \pm 0.48$ & $28.04 \pm 1.09$ & $6 \pm 0.07$ & $1.27 \pm 0.13$ & $>100$ & $0.55 \pm 0.03$ & 0.43 \\
\hline
\end{tabular}

[a] HeLa (cervical cancer cell line); [b] Hep G2 (hepatocarcinoma cell line); [c] MCF-7 (breast cancer cell line); [d] FaDu (head and neck squamous carcinoma cell line); [e] A549 (epithelial cancer cell line); [f] MCF 10A (normal mammary epithelial cell); [g] SI: selectivity index. It was calculated as: $\mathrm{SI}=\mathrm{IC}_{50}(\mathrm{MCF} 10 \mathrm{~A}) / \mathrm{IC}_{50}(\mathrm{FaDu})$; $[\mathrm{h}] \mathrm{NC}$ : not calculated.

\subsection{Colony Formation Assay}

As ligustrazine dimer 8e had the most potent antiproliferative activity in all synthesized compounds, the colony formation assay in FaDu cells was conducted. As shown in Figure 2, $\mathrm{FaDu}$ cells treated with compound $8 \mathrm{e}$ at concentrations $0.75 \mathrm{nM}, 1.50 \mathrm{nM}, 3 \mathrm{nM}, 6 \mathrm{nM}$ for 10 days formed smaller and fewer colonies compared to untreated control group, indicating that compound 8e had a dose-dependent inhibition on the proliferation of FaDu cells, and the colony inhibition rate reached around $85.4 \%$ at $6 \mathrm{nM}$. 

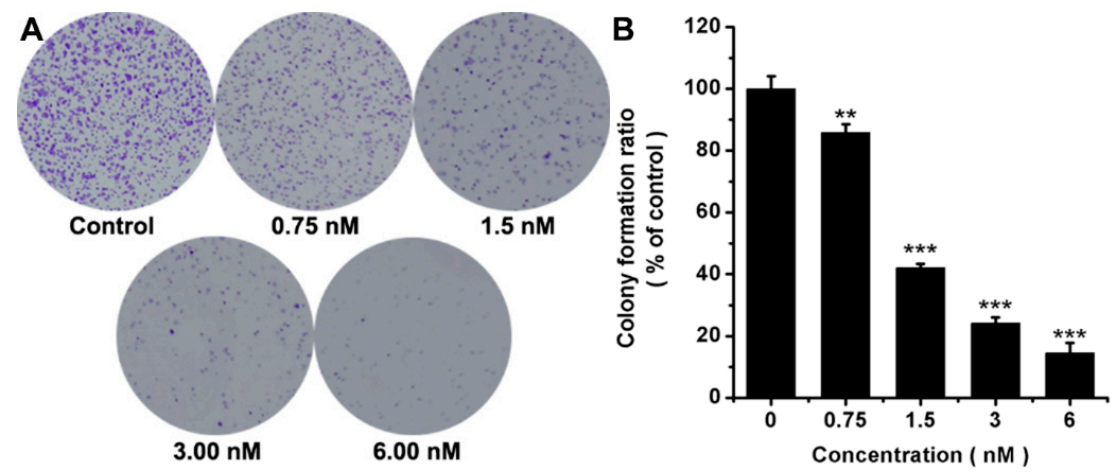

Figure 2. Effect of 8e on the colony formation in FaDu cells. (A) Representative images of FaDu colonies after treatment at the indicated concentrations for 10 days; (B) The percentage of colonies compared with control group, $n=3$. $^{* *}: p<0.01{ }^{* * *}: p<0.001$ versus control.

\subsection{Live/Dead Staining}

Live-dead double staining experiment was conducted to visually evaluate the cell toxicity of compound 8e, the most potent one obtained by MTT assay. Propidium iodide (PI)-stained dead cells in red and calcein AM-stained living cells in green. The number of dead cells increased with the dose of $8 \mathbf{e}$ while living cells decreased. Simultaneously, the densities of $\mathbf{8 e}$-treated cells were much lower than that of the control group. The concentration-dependent loss of $\mathrm{FaDu}$ cell viability was consistent with the MTT results (Figure 3).

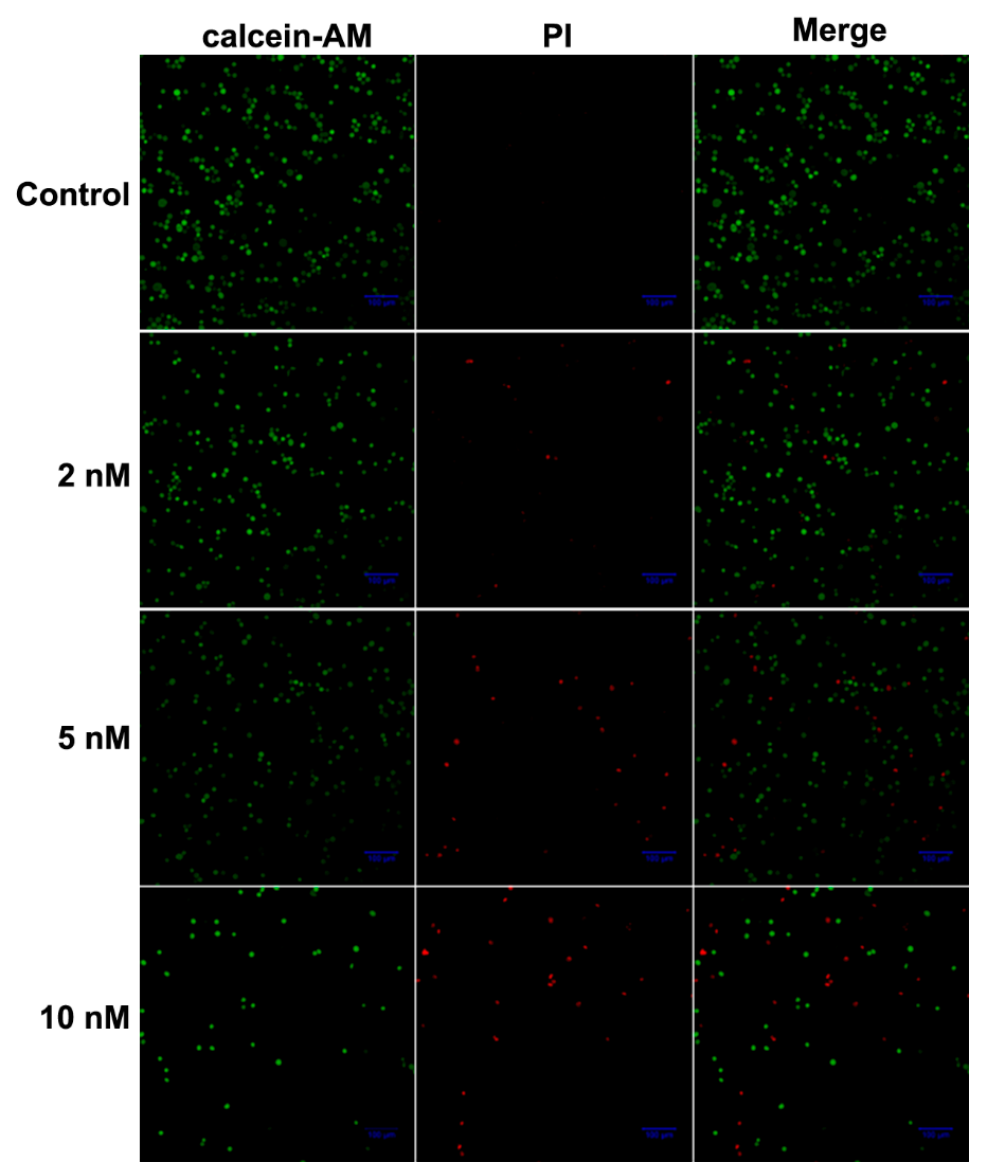

Figure 3. The confocal images of FaDu cells after incubation with compound $8 \mathbf{e}$ at concentrations of 0 , 2, 5, and $10 \mathrm{nM}$ for $24 \mathrm{~h}$, respectively. Viable cells were stained in green with Calcein-AM, and dead cells were stained in red with PI. The scale bar was $100 \mu \mathrm{m}$. 


\subsection{Morphological Observation by Hoechst 33,342 Staining}

To investigate whether the anti-proliferation behavior of $8 \mathbf{e}$ was related to the apoptosis pathway, the interaction between 8e- and FaDu cells was analyzed through Hoechst 33,342 staining with a laser scanning confocal microscope. As shown in Figure 4, cells without treatment as the control group exhibited almost negligible apoptotic characteristics with homogenous and round blue-stained nuclei. On the contrary, the typical apoptotic nuclei with irregular nuclear morphology and condensation of chromatin (much brighter stained cells) were observed, and most FaDu cells were shrunken and rounded up from the culture dish after exposure to $8 \mathbf{e}$. The result demonstrated that inducing apoptosis in FaDu cells might be one cause of cell growth inhibition by compound $\mathbf{8 e}$.

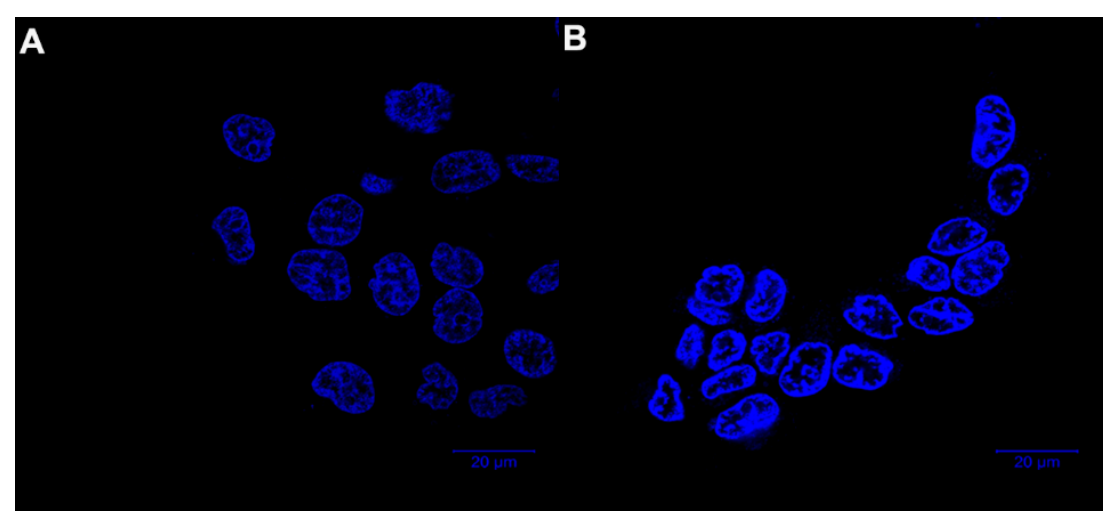

Figure 4. Hoechst staining of FaDu cells treated with compound 8e, (A) Control group; (B) $20 \mathrm{nM}$ group.

\subsection{Apoptosis Analysis by Annexin V-FITC/PI Staining}

To substantiate whether the cell death induced by the ligustrazine dimer $8 \mathbf{e}$ was associated with apoptosis, the interaction of FaDu cells with $8 \mathbf{e}$ was further analyzed by an annexin V-FITC/PI staining, and the apoptosis ratios were quantitated by flow cytometry. The cells were divided into four quadrants: Q1 represented necrotic cells (annexin $\mathrm{V}^{-} / \mathrm{PI}^{+}$), Q2 represented late apoptotic cells (annexin $\mathrm{V}^{+} / \mathrm{PI}^{+}$), Q3 represented early apoptotic cells (annexin $\mathrm{V}^{+} / \mathrm{PI}^{-}$), Q4 represented living cells (annexin $\left.\mathrm{V}^{-} / \mathrm{PI}^{-}\right)$. As shown in Figure 5, after being exposed to different concentrations of $8 \mathbf{e}(2,5,10$ $\mathrm{nM}$ ) for $24 \mathrm{~h}$ in FaDu cells, the apoptotic cells (including the early and late apoptosis ratios) increased gradually from $8.23 \%$ of the control to $34.2 \%, 57.7 \%, 79.5 \%$, respectively. The results revealed that 8e could induce FaDu cells' apoptosis in a dose-dependent manner. This was consistent with other reports showing TMP and its derivatives could induce apoptosis of cancer cells [22-24]. 

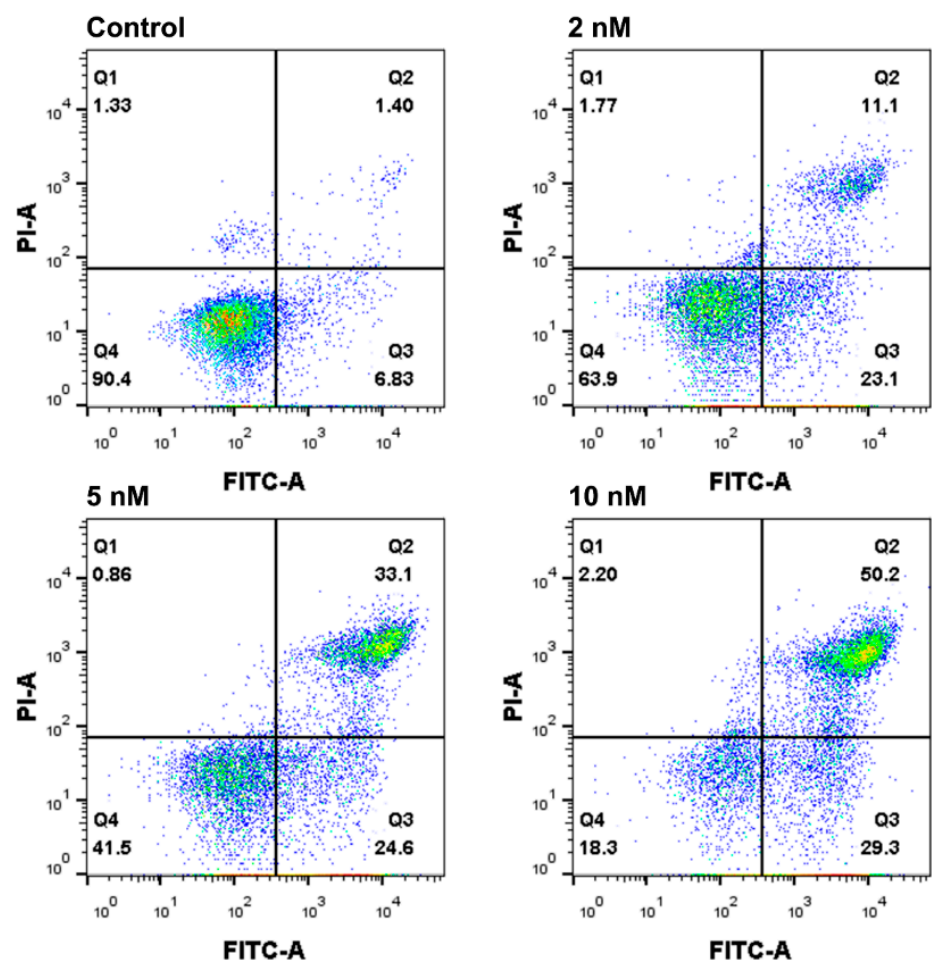

Figure 5. Flow cytometry analysis of apoptosis using annexin V-FITC/PI double staining in FaDu cells treated with compound $\mathbf{8 e}$ at the indicated concentrations for $24 \mathrm{~h}$. The percentage of cells was given in the respective quadrants.

\subsection{Mitochondrial Membrane Potential ( $\Delta \Psi m)$ Analysis}

Mitochondria play an essential role in cell apoptotic progression by regulating mitochondrial membrane potential $(\Delta \Psi \mathrm{m})$. Depolarization of $\Delta \Psi \mathrm{m}$ is considered an indicator of cell apoptosis [25]. To better understand the mechanism of 8e-induced FaDu cells apoptosis, the depolarization of $\Delta \Psi \mathrm{m}$ was quantitated by JC-1 (tetraethylbenzimidazolylcarbocyanine iodide) dye. As a mitochondrial-specific dual-fluorescence probe, JC-1 selectively entered the mitochondria. In healthy cells with high $\Delta \Psi \mathrm{m}$, it accumulated in the mitochondrial matrix as J-aggregates with red fluorescence, while in the reduced $\Delta \Psi \mathrm{m}$ cells, it remained in the cytoplasm as a monomer with green fluorescence. The change of $\Delta \Psi \mathrm{m}$ could be easily detected by the change of fluorescence color. Flow cytometric analysis of FaDu cells treated with different concentrations of $8 \mathbf{e}(2,5,10 \mathrm{nM})$ for $24 \mathrm{~h}$ revealed that the ratio of green to red fluorescence was significantly higher than that of the control group in a concentration-dependent manner, indicating that the number of lower $\Delta \Psi \mathrm{m}$ cells increased (Figure 6). These results suggested that $8 \mathbf{e}$ could induce apoptosis of FaDu cells by decreasing $\Delta \Psi \mathrm{m}$. 

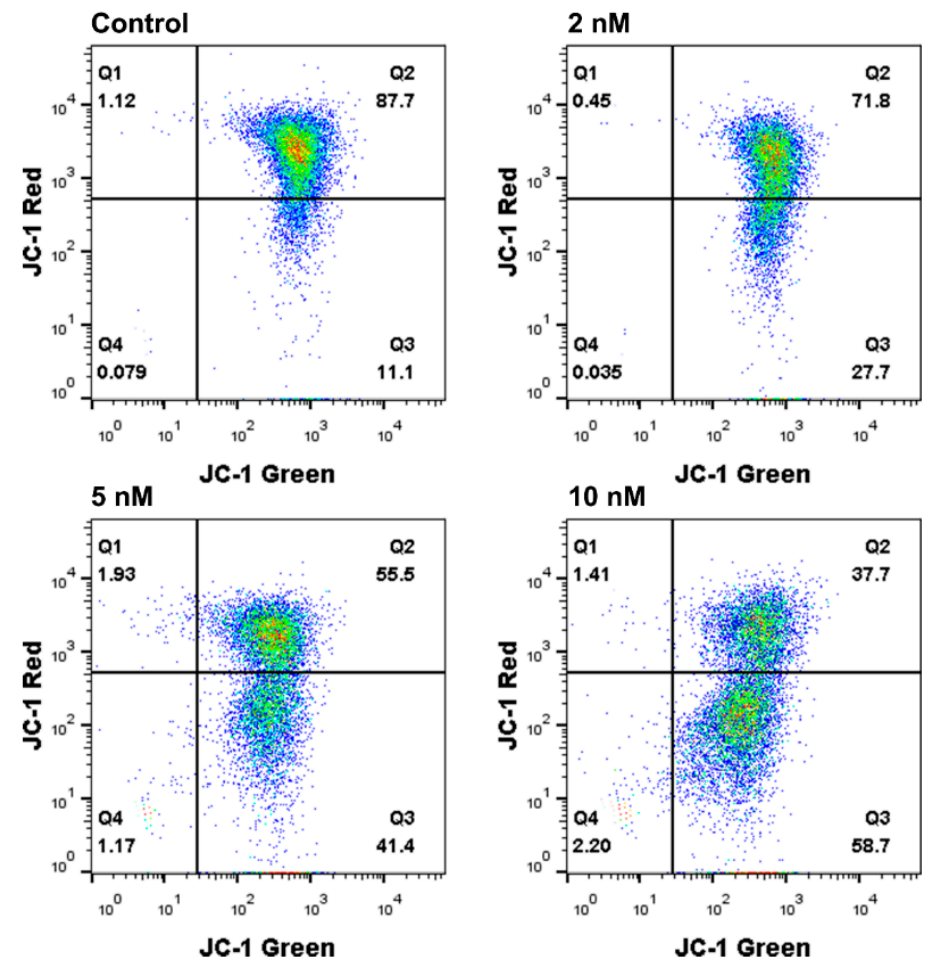

Figure 6. Flow cytometry analysis of the mitochondrial membrane potential using the JC-1 (tetraethylbenzimidazolylcarbocyanine iodide) dye in FaDu cells treated with compound 8e at the indicated concentrations for $24 \mathrm{~h}$. The percentage of cells was given in the respective quadrants.

\subsection{Cell Cycle Analysis}

In order to investigate whether 8 e induced cell cycle disturbances in FaDu cells, the flow cytometric analysis was performed with PI staining. The fluorescence intensity was proportional to the content of double-stranded DNA. The separation of cells in G0/G1, S, and G2/M was based upon the distribution of DNA content. Cytometric profiles of the PI-stained DNA showed that after being treated with $8 \mathbf{e}$ at different concentrations $(2,5,10 \mathrm{nM})$ for $24 \mathrm{~h}$, the cell cycle of FaDu cells was arrested. As shown in Figure 7, the percentage of cells in the S phase (33.7\%, $44.3 \%$, and $54.7 \%)$ was markedly improved compared with the control group (28.1\%), and this effect was concentration-dependent in FaDu cells. The population of the G0/G1 phase decreased from $51.9 \%$ to $41.8 \%, 44.2 \%$, and $32.4 \%$, respectively. These data indicated that $8 \mathbf{e}$ significantly arrested cell cycle at $\mathrm{S}$ phase. This was different from the previously reported cell cycle arrest in the G0/G1 phase induced by TMP [4], which revealed that the dimerization of TMP could change the modulation of the cell cycle of its monomer. 
A
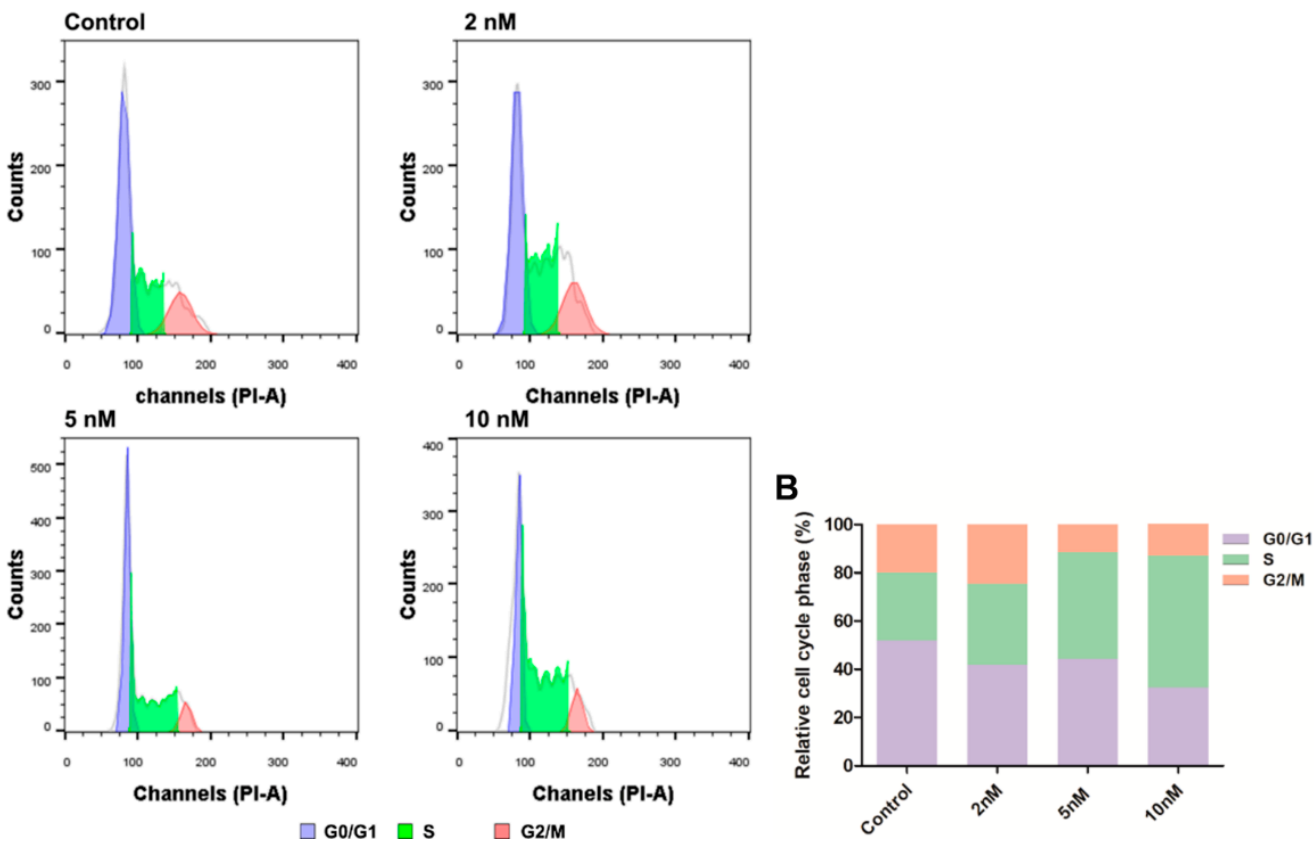

Figure 7. Flow cytometry analysis for cell cycle distribution of FaDu cells. (A) Representative cell cycle distribution of FaDu cells with compound 8e treatment $(0,2,5$, and $10 \mathrm{nM})$ for $24 \mathrm{~h}$. The tall peak (left) represents cells in the G0/G1 phase, the small peak (right) represents cells in the G2/M phase, and the middle area represents cells in the $S$ phase. (B) Quantification of the percentage of cell cycle distribution.

\subsection{In Silico ADMET Prediction}

ADMET prediction is becoming increasingly crucial as most drugs fail in clinical trials owing to poor pharmacokinetic parameters [26,27]. Table 2 shows the ADMET calculated descriptors for our synthesized compounds and two biplots shown in Figure 8. All compounds had 0-4 HBD (hydrogen bond donor) and 4-10 HBA (hydrogen bond acceptor), which were under Lipinski's rule of five (HBD $<5$, HBA $<10$ ). PPB (plasma protein binding) was one of the key properties related to drug efficacy. Except for compounds 10-15e, 17-24e, and 9d, most of the compounds had weak $(<90 \%)$ binding with plasma proteins in the blood, which were predicted to be non-inhibitors of cytochrome P450 2D6, and participated in the good- metabolism of phase I metabolism. $\mathrm{T}_{1 / 2}$ of the target molecules was in the range of 1.63-2.29 h, showing the characteristic of rapid metabolism. The HT (hepatotoxicity) values estimated the hepatoxicity of the chemical compounds. HT values for series $\mathbf{6 a - i}, \mathbf{1 3}-\mathbf{1 4 e}, \mathbf{2 0 e}$, 29e, 31-35e, 9f, 9i, 9k, and 9m were zero, and there was no hepatoxicity, while other compounds might be hepatotoxic. Moreover, the $\mathrm{LD}_{50}$ (median lethal dose) predicted that series 8a-f, 9-35e, and 9d-m were over $500 \mathrm{mg} / \mathrm{kg}$, implying they were less toxic. In addition, an ADMET model formed with descriptors 2D polar surface area (PSA) and AlogP98 could predict human intestinal absorption and the blood-brain barrier penetration (BBB) at $95 \%$ and $99 \%$ confidence level. In the absorption plot, compounds $6 \mathbf{a}-\mathbf{f}, \mathbf{6 h}-\mathbf{i}, \mathbf{8 a}-\mathbf{f}, \mathbf{9 - 1 1 e}, \mathbf{1 3 - 1 9 e}, \mathbf{2 3 e}, \mathbf{3 0 - 3 3 e , 9 d , 9 g}$, and $\mathbf{9 j}-\mathrm{m}$ were predicted to be easily absorbed by the intestine at $99 \%$ confidence level. While in the BBB plot, the most potent compounds $8 \mathbf{e}$ and $\mathbf{8 f}$ were fallen out of the $99 \%$ ellipse (undefined), suggesting its poor blood-brain barrier penetration ability. Therefore, these molecules might possess low or no side effects of the central nervous system (CNS). In conclusion, ADMET prediction of the compounds might be helpful for further designing new drugs with favorable oral bioavailability. 
Table 2. The ADMET properties of all synthetic compounds.

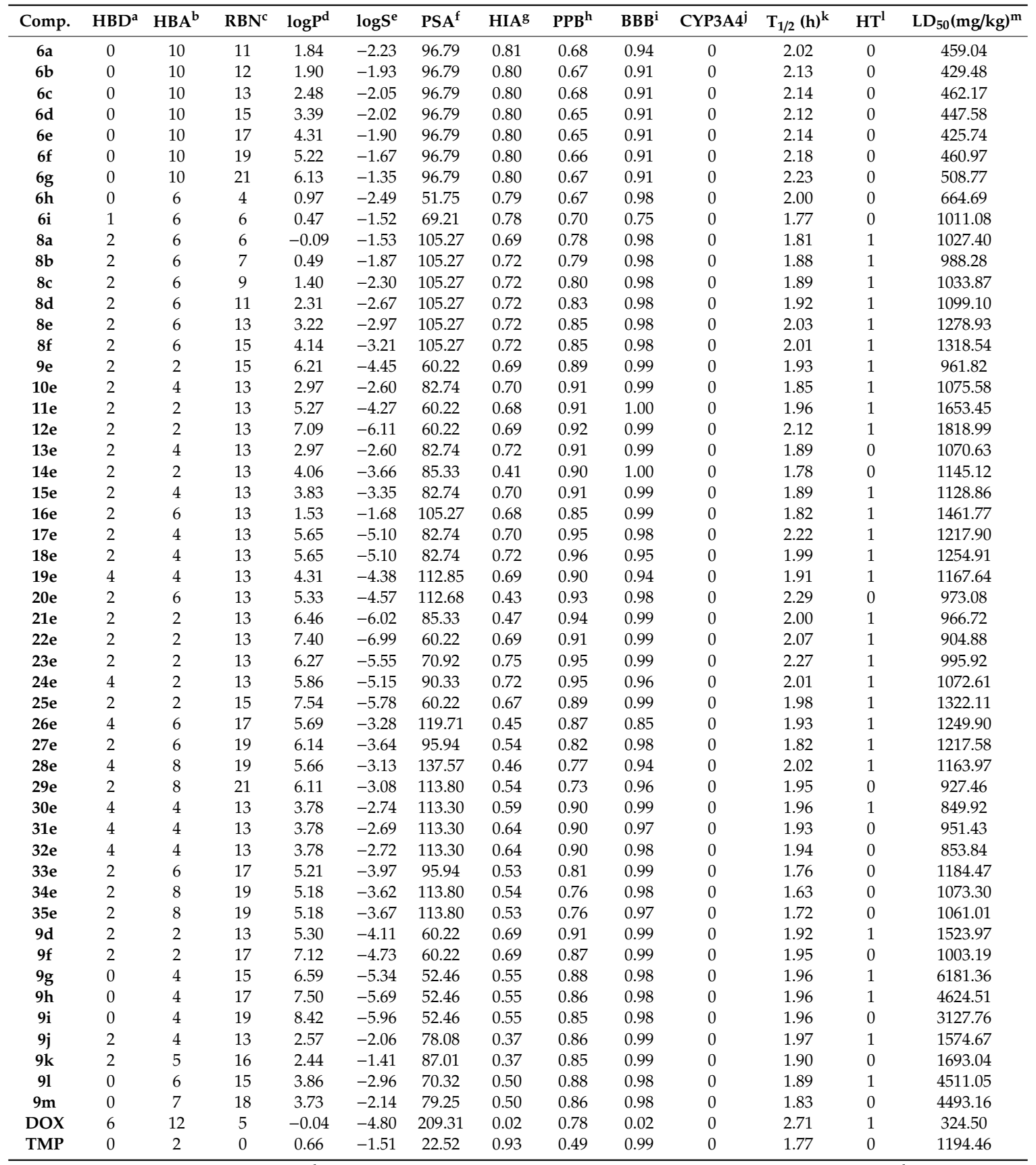

${ }^{\mathrm{a}}$ HBD (hydrogen bond donor), ${ }^{\mathrm{b}}$ HBA (hydrogen bond acceptor), ${ }^{\mathrm{c}} \mathrm{RBN}$ (number of rotatable bonds), ${ }^{\mathrm{d}} \log \mathrm{P}(\log$ of the octanol/water partition coefficient), ${ }^{\mathrm{e}} \log \mathrm{S}$ ( $\log$ of the aqueous solubility), and ${ }^{\mathrm{f}} \mathrm{PSA}$ (polar surface area) were predicted using Discovery Studio 2.0 software. ${ }^{\mathrm{g}}$ HIA (human intestinal absorption), ${ }^{\mathrm{h}}$ PPB (plasma protein binding), ${ }^{\mathrm{I}}$ CYP3D4 (CYP3D4 inhibition), ${ }^{\mathrm{j}} \mathrm{T} 1 / 2$ (half lifetime), ${ }^{\mathrm{k}} \mathrm{HT}$ (human hepatoxicity), and ${ }^{\mathrm{l}} \mathrm{LD} 50$ (median lethal dose) were calculated via http://admet.scbdd.com/home/index/ 


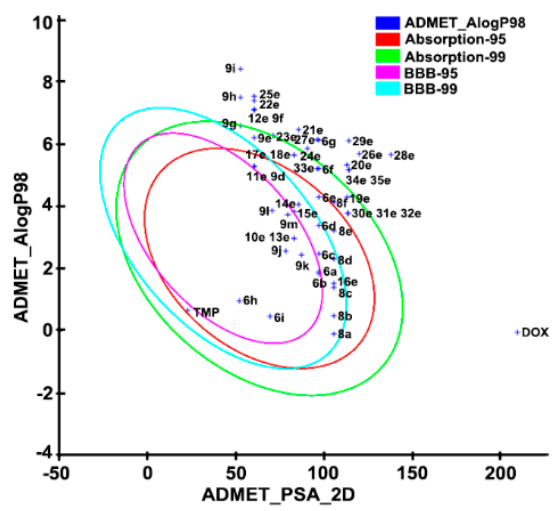

Figure 8. The plot of PSA (polar surface area) versus AlogP98 for the newly synthesized compounds showing the $95 \%$ and $99 \%$ confidence limit ellipses corresponding to the intestinal absorption and blood-brain barrier models.

\section{Conclusions}

Using ligustrazine, aromatic, or heteroaromatic acids as the main raw materials and linked by alkyl or ether chain, bivalent antitumor agents were synthesized and screened from five different human cancer cell lines and one normal mammary epithelial cell line. SAR revealed that the two terminal amide bonds and the alky chain were the dominant factors with $10 \mathrm{C}$ atom chain showing the most potent antitumor effect. Among different aromatic moieties, the ligustrazine dimer $\mathbf{8 e}$ was the best candidate; its $\mathrm{IC}_{50}$ was $1.36 \mathrm{nM}$ in FaDu cell, it showed a broad-spectrum antitumor activity with $\mathrm{IC}_{50}$ in the range of $0.00136-1.42 \mu \mathrm{M}$, and the selective ratio MCF $10 \mathrm{~A} / \mathrm{FaDu}$ was 34.56 . The subsequent fluorescence staining and flow cytometry analysis indicated that $8 \mathbf{e}$ could induce apoptosis through depolarization of the mitochondrial membrane potential in FaDu cells. Further mechanism investigation showed that 8e could arrest cell cycle at the $\mathrm{S}$ phase in FaDu cells. Furthermore, ADMET predicted that most of the potent compounds followed Lipinski's law and became 'drug-like' molecules, further confirming that the dimerization of ligustrazine could improve the antitumor activity of its monomer. The highly selective inhibition of these dimers on the proliferation of FaDu cells might be related to the effect on a specific target in FaDu cells. Based on the characteristics of FaDu cells, further targeted screening would give insight into the selectivity of such potent compounds.

\section{Materials and Methods}

\subsection{Chemistry}

${ }^{1} \mathrm{H}-\mathrm{NMR}$ and ${ }^{13} \mathrm{C}-\mathrm{NMR}$ spectra were recorded on a Mercury Vx-300 (300 MHz) or AVANCE III $(400 \mathrm{MHz})$. Chemical shifts were reported in ppm $(\delta)$ using the residue solvent line as the internal standard (for TMS: $0 \mathrm{ppm},{ }^{1} \mathrm{H}$ and ${ }^{13} \mathrm{C}$; for $\mathrm{CHCl}_{3}-d$ : $7.26 \mathrm{ppm},{ }^{1} \mathrm{H}$ and $77.16 \mathrm{ppm},{ }^{13} \mathrm{C}$ ). Coupling constants were given in Hertz (J). High-resolution MS (HRMS) were recorded on an Agilent 6520 Q-TOF LC/MS. Melting points were uncorrected and were determined on a digital melting point apparatus (Shenguang WRS-1B, shanghai, China). Flash column chromatography was carried out by using silica gel (200-300 mesh). Reactions were monitored by thin-layer chromatography (TLC) on silica gel GF254 plates (Qingdao Haiyang Chemical Plant, Qingdao, China). Reagents and solvents were used as purchased from commercial sources without further purification. The purity of the synthesized compounds was over $95 \%$ analyzed by HPLC (Waters 2695 Alliance system, Waters Corp., Milford, MA, USA), with the Kromasil C18 column eluted by methanol/water (80/20) containing $0.1 \%$ trifluoroacetic acid at a flow rate of $1 \mathrm{~mL} / \mathrm{min}$. Compounds 4 and 5 were prepared, as reported previously [19]. ${ }^{1} \mathrm{H}-\mathrm{NMR},{ }^{13} \mathrm{C}-\mathrm{NMR}$ and HR-MS spectra of compounds $\mathbf{6 a}-\mathbf{9 m}$ can be seen in supplementary materials. 


\subsection{General Synthetic Procedure for $\mathbf{6 a}-\mathbf{g}$}

A mixture of alkane-diamine (10 mmol), TMP-Cl $(50 \mathrm{mmol}), \mathrm{KOH}(60 \mathrm{mmol})$, and dimethylformamide $(35 \mathrm{~mL})$ was heated to reflux. The reaction progress was monitored via TLC. After $2 \mathrm{~h}$, the reaction mixture was cooled to room temperature. Subsequently, the solid was filtered off, and the filtrate was added with $\mathrm{H}_{2} \mathrm{O}(100 \mathrm{~mL})$ and extracted with ethyl acetic acid three times. The organic layers were combined and washed with $\mathrm{H}_{2} \mathrm{O}$ and brine, and then separated and dried over anhydrous $\mathrm{Na}_{2} \mathrm{SO}_{4}$ for $8 \mathrm{~h}$. The solvent was removed under reduced pressure; the resulting residue was separated on flash column chromatography eluted by a mixture of petroleum ether/acetone in a volume ratio of 7:1-3:1, and further recrystallized from acetone to give pale white solid.

\subsection{1. $\mathrm{N}^{1}, \mathrm{~N}^{1}, \mathrm{~N}^{2}, \mathrm{~N}^{2}$-Tetrakis((3,5,6-Trimethylpyrazin-2-yl)Methyl)Ethane-1,2-Diamine (6a)}

Pale white solid, yield $28 \%$, m.p. $207.6-208.3{ }^{\circ} \mathrm{C} ;{ }^{1} \mathrm{H}-\mathrm{NMR}\left(300 \mathrm{MHz}, \mathrm{CDCl}_{3}\right) \delta: 3.60(\mathrm{~s}, 8 \mathrm{H})$, $2.67(\mathrm{~s}, 4 \mathrm{H}), 2.43(\mathrm{~s}, 12 \mathrm{H}), 2.41(\mathrm{~s}, 12 \mathrm{H}), 2.23(\mathrm{~s}, 12 \mathrm{H}) ;{ }^{13} \mathrm{C}-\mathrm{NMR}(101 \mathrm{MHz}, \mathrm{DMSO}) \delta: 149.91,149.63$, $148.37,147.85,58.75,52.14,50.83,21.61,21.42,20.65$; HRMS (ESI) m/z: $597.4134[\mathrm{M}+\mathrm{H}]^{+}$, calcd. for $\left[\mathrm{C}_{34} \mathrm{H}_{49} \mathrm{~N}_{10}\right]^{+}$597.4142.

\subsection{2. $\mathrm{N}^{1}, \mathrm{~N}^{1}, \mathrm{~N}^{3}, \mathrm{~N}^{3}$-Tetrakis((3,5,6-Trimethylpyrazin-2-yl)Methyl)Propane-1,3-Diamine (6b)}

Pale white solid, yield 27\%, m.p. $113-114.3^{\circ} \mathrm{C} ;{ }^{1} \mathrm{H}-\mathrm{NMR}\left(300 \mathrm{MHz}, \mathrm{CDCl}_{3}\right) \delta: 3.65$ (s, 8H), 2.46 (s, 12H), $2.43(\mathrm{~s}, 12 \mathrm{H}), 2.41-2.38(\mathrm{~m}, 4 \mathrm{H}), 2.32(\mathrm{~s}, 12 \mathrm{H}), 1.81-1.71(\mathrm{~m}, 2 \mathrm{H}) .{ }^{13} \mathrm{C}-\mathrm{NMR}(101 \mathrm{MHz}, \mathrm{DMSO}) \delta$ : 149.93, 149.53, 148.51, 147.82, 58.63, 53.36, 21.61, 21.44, 20.70; HRMS (ESI) $m / z: 611.4286[\mathrm{M}+\mathrm{H}]^{+}$, calcd. for $\left[\mathrm{C}_{35} \mathrm{H}_{51} \mathrm{~N}_{10}\right]^{+} 611.4298$.

\subsection{3. $\mathrm{N}^{1}, \mathrm{~N}^{1}, \mathrm{~N}^{4}, \mathrm{~N}^{4}$-Tetrakis((3,5,6-Trimethylpyrazin-2-yl)Methyl)Butane-1,4-Diamine (6c)}

Pale white solid, yield 37\%, m.p. $129.2-129.5{ }^{\circ} \mathrm{C} ;{ }^{1} \mathrm{H}-\mathrm{NMR}\left(300 \mathrm{MHz}, \mathrm{CDCl}_{3}\right) \delta: 3.62(\mathrm{~s}, 8 \mathrm{H})$, $2.44(\mathrm{~s}, 24 \mathrm{H}), 2.40-2.37(\mathrm{~m}, 4 \mathrm{H}), 2.30(\mathrm{~s}, 12 \mathrm{H}), 1.37$ (s, 4H); ${ }^{13} \mathrm{C}-\mathrm{NMR}$ (101 MHz, DMSO) $\delta: 150,149.53$, 148.60, 147.79, 58.54, 54.85, 24.39, 21.64, 21.47, 20.71; HRMS (ESI) $\mathrm{m} / z: 625.4451[\mathrm{M}+\mathrm{H}]^{+}$, calcd. for $\left[\mathrm{C}_{36} \mathrm{H}_{53} \mathrm{~N}_{10}\right]^{+} 625.4455$.

\subsection{4. $\mathrm{N}^{1}, \mathrm{~N}^{1}, \mathrm{~N}^{6}, \mathrm{~N}^{6}$-Tetrakis((3,5,6-Trimethylpyrazin-2-yl)Methyl)Hexane-1,6-Diamine (6d)}

Pale white solid, yield 43\%, m.p. 146.7-147.9 ${ }^{\circ} \mathrm{C} ;{ }^{1} \mathrm{H}-\mathrm{NMR}\left(300 \mathrm{MHz}, \mathrm{CDCl}_{3}\right) \delta: 3.67(\mathrm{~s}, 8 \mathrm{H})$, 2.46-2.45 (m, 24H), 2.43-2.40 (m, 4H), $2.34(\mathrm{~s}, 12 \mathrm{H}), 1.43(\mathrm{br}, 4 \mathrm{H}), 1.04(\mathrm{br}, 4 \mathrm{H}) ;{ }^{13} \mathrm{C}-\mathrm{NMR}(101 \mathrm{MHz}$, DMSO) $\delta: 150.05,149.48,148.71,147.77,58.64,54.93,27.34,26.56,21.65,21.48,20.74$; HRMS (ESI) $m / z$ : $653.4765[\mathrm{M}+\mathrm{H}]^{+}$, calcd. for $\left[\mathrm{C}_{38} \mathrm{H}_{57} \mathrm{~N}_{10}\right]^{+} 653.4768$.

\subsection{5. $\mathrm{N}^{1}, \mathrm{~N}^{1}, \mathrm{~N}^{8}, \mathrm{~N}^{8}$-Tetrakis((3,5,6-Trimethylpyrazin-2-yl)Methyl)Octane-1,8-Diamine (6e)}

Pale white solid, yield 48\%, m.p. $107.8-108.6{ }^{\circ} \mathrm{C} ;{ }^{1} \mathrm{H}-\mathrm{NMR}\left(300 \mathrm{MHz}, \mathrm{CDCl}_{3}\right) \delta: 3.67(\mathrm{~s}, 8 \mathrm{H}), 2.45$ (br, 24H), 2.42-2.38 (m, 4H), $2.34(\mathrm{~s}, 12 \mathrm{H}), 1.48-1.40(\mathrm{~m}, 4 \mathrm{H}), 1.05(\mathrm{br}, 8 \mathrm{H}) ;{ }^{13} \mathrm{C}-\mathrm{NMR}\left(101 \mathrm{MHz}, \mathrm{CDCl}_{3}\right)$ $\delta: 150.09,149.47,148.75,147.76,58.69,54.90,29.52,27.46,26.55,21.65,21.47,20.73$; HRMS (ESI) $m / z$ : $681.5076[\mathrm{M}+\mathrm{H}]^{+}$, calcd. for $\left[\mathrm{C}_{40} \mathrm{H}_{61} \mathrm{~N}_{10}\right]^{+} 681.5081$.

\subsection{6. $\mathrm{N}^{1}, \mathrm{~N}^{1}, \mathrm{~N}^{10}, \mathrm{~N}^{10}$-Tetrakis((3,5,6-Trimethylpyrazin-2-yl)Methyl)Decane-1,10-Diamine (6f)}

Pale white solid, yield 76\%, m.p. $67.4-68{ }^{\circ} \mathrm{C} ;{ }^{1} \mathrm{H}-\mathrm{NMR}\left(300 \mathrm{MHz}, \mathrm{CDCl}_{3}\right) \delta: 3.69$ (s, 8H), 2.46 (br, 24H), 2.41-2.39 (m, 4H), 2.35 (s, 12H), 1.47 (br, 4H), 1.11 (br, 12H); ${ }^{13} \mathrm{C}-\mathrm{NMR}(101 \mathrm{MHz}, \mathrm{DMSO}) \delta$ : 150.10, 149.45, 148.78, 147.76, 58.71, 54.92, 29.73, 29.52, 27.48, 26.57, 21.64, 21.47, 20.74; HRMS (ESI) $m / z$ : $709.5378[\mathrm{M}+\mathrm{H}]^{+}$, calcd. for $\left[\mathrm{C}_{42} \mathrm{H}_{65} \mathrm{~N}_{10}\right]^{+} 709.5394$.

\subsection{7. $\mathrm{N}^{1}, \mathrm{~N}^{1}, \mathrm{~N}^{12}, \mathrm{~N}^{12}$-Tetrakis((3,5,6-Trimethylpyrazin-2-yl)Methyl)Dodecane-1,12-Diamine (6g)}

Pale white solid, yield 76\%, m.p. 84.7-85.3 ${ }^{\circ} \mathrm{C} ;{ }^{1} \mathrm{H}-\mathrm{NMR}\left(300 \mathrm{MHz}, \mathrm{CDCl}_{3}\right) \delta: 3.69$ (s, 8H), 2.46 (br, 24H), $2.44(\mathrm{br}, 4 \mathrm{H}), 2.35$ (s, 12H), $1.47(\mathrm{br}, 4 \mathrm{H}), 1.15-1.12(\mathrm{br}, 16 \mathrm{H}) ;{ }^{13} \mathrm{C}-\mathrm{NMR}(101 \mathrm{MHz}, \mathrm{DMSO}) \delta$ : 
150.10, 149.44, 148.78, 147.74, 58.72, 54.89, 29.75, 29.53, 27.46, 26.56, 21.64, 21.47, 20.73; HRMS (ESI) $m / z$ : $737.5689[\mathrm{M}+\mathrm{H}]^{+}$, calcd. for $\left[\mathrm{C}_{44} \mathrm{H}_{69} \mathrm{~N}_{10}\right]^{+} 737.5707$.

\subsection{1,4-Bis((3,5,6-Trimethylpyrazin-2-yl)Methyl)Piperazine (6h)}

A mixture of piperazine $(0.800 \mathrm{~g}, 9.29 \mathrm{mmol}), \mathrm{TMP}-\mathrm{Cl}(3.80 \mathrm{~g}, 22.29 \mathrm{mmol}), \mathrm{KOH}(1.56 \mathrm{~g}, 27.66$ $\mathrm{mmol})$, and dimethylformamide $(20 \mathrm{~mL})$ was heated under reflux for $2 \mathrm{~h}$. The reaction was monitored by TLC. The reaction was quenched, filtered, and the filtrate was added with $100 \mathrm{~mL} \mathrm{H}_{2} \mathrm{O}$ and extracted with ethyl acetate three times. The organic layers were combined, washed with $\mathrm{H}_{2} \mathrm{O}$ and brine, and then dried over anhydrous $\mathrm{Na}_{2} \mathrm{SO}_{4}$ for $8 \mathrm{~h}$. The solvent was evaporated in vacuo. The resulting residue was separated on flash column chromatography with a mixture of petroleum ether/acetone 7:1-3:1(volume ratio) as eluent, and then further recrystallized from acetone to afford compound $\mathbf{6 h}$.

Pale white solid, yield $62 \%$, m.p. $155.8-156.3{ }^{\circ} \mathrm{C} ;{ }^{1} \mathrm{H}-\mathrm{NMR}\left(300 \mathrm{MHz}, \mathrm{CDCl}_{3}\right) \delta: 3.58(\mathrm{~s}, 4 \mathrm{H}), 2.55$ (s, 8H), 2.47 (br, 18H); ${ }^{13} \mathrm{C}-\mathrm{NMR}(101 \mathrm{MHz}, \mathrm{DMSO}) \delta: 150.01,149.57,148.10,147.98,61.88,53.26,50.70$, 21.61, 21.51, 21.04; HRMS (ESI) $m / z: 355.2610[\mathrm{M}+\mathrm{H}]^{+}$, calcd. for $\left[\mathrm{C}_{20} \mathrm{H}_{31} \mathrm{~N}_{6}\right]^{+} 355.2610$.

\subsection{2-(Bis((3,5,6-Trimethylpyrazin-2-yl)Methyl)Amino)Ethanol (6i)}

A mixture of ethanolamine $(0.500 \mathrm{~g}, 8.19 \mathrm{mmol}), \mathrm{TMP}-\mathrm{Cl}(3.35 \mathrm{~g}, 19.65 \mathrm{mmol}), \mathrm{K}_{2} \mathrm{CO}_{3}(3.39 \mathrm{~g}$, $24.56 \mathrm{mmol})$, and acetonitrile $(20 \mathrm{~mL})$ was heated under reflux for $3 \mathrm{~h}$. The product formation was monitored via TLC. After cooling, the mixture was filtered, and the filtrate was evaporated in vacuo. The residue was purified by flash column chromatography with an eluent of petroleum ether/acetone $=10: 1-3: 1$ to afford compound $\mathbf{6 i}$.

Light yellow oil, yield 72\%; ${ }^{1} \mathrm{H}-\mathrm{NMR}\left(300 \mathrm{MHz}, \mathrm{CDCl}_{3}\right) \delta: 3.82(13 \mathrm{~s}, 4 \mathrm{H}), 3.66(\mathrm{t}, J=5 \mathrm{~Hz}, 2 \mathrm{H})$, $2.87(\mathrm{t}, J=5.1 \mathrm{~Hz}, 2 \mathrm{H}), 2.41(\mathrm{~s}, 6 \mathrm{H}), 2.37(\mathrm{~s}, 6 \mathrm{H}), 2.35(\mathrm{~s}, 6 \mathrm{H}) ;{ }^{13} \mathrm{C}-\mathrm{NMR}(101 \mathrm{MHz}, \mathrm{DMSO}) \delta:$ 149.54, 148.94, 148.27, 147.87, 59.67, 58.15, 57.36, 21.41, 21.21, 20.52; HRMS (ESI) $m / z: 330.2290[\mathrm{M}+\mathrm{H}]^{+}$, calcd. for $\left[\mathrm{C}_{18} \mathrm{H}_{28} \mathrm{~N}_{5} \mathrm{O}\right]^{+} 330.2294$.

\subsection{General Synthetic Procedure for $\mathbf{8} \mathbf{a}-\mathbf{f}$}

Compound 7 was gained according to the method described by $\mathrm{Wu}$ [20]. A mixture of tetramethylpyrazine acid $(4.40 \mathrm{mmol}), \mathrm{EDCI}(4.72 \mathrm{mmol})$, triethylamine $(12 \mathrm{mmol})$, DMAP $(2.40$ $\mathrm{mmol})$, and anhydrous dichloromethane $(10 \mathrm{~mL})$ was stirred to dissolve, then diamino-alkane (2 $\mathrm{mmol}$ ) was added and stirred at room temperature until the reaction was finished (monitored by TLC). The reaction mixture was washed with brine and water, extracted with dichloromethane $(20 \mathrm{~mL})$, dried over anhydrous sodium sulfate for $8 \mathrm{~h}$, filtered, and the solvent was evaporated. The resulting residue was purified by flash column chromatography with an eluent of petroleum ether/acetone = 15:1-3:1(volume ratio) to give pale white solid.

4.5.1. N,N'-(Propane-1,3-Diyl)Bis(3,5,6-Trimethylpyrazine-2-Carboxamide) (8a)

Pale white solid, yield 16\%, m.p. $125.4-126.4{ }^{\circ} \mathrm{C} ;{ }^{1} \mathrm{H}-\mathrm{NMR}\left(300 \mathrm{MHz}, \mathrm{CDCl}_{3}\right) \delta: 8.30(\mathrm{t}, J=5.9$ $\mathrm{Hz}, 2 \mathrm{H}), 3.58-3.52(\mathrm{~m}, 4 \mathrm{H}), 2.92(\mathrm{~s}, 6 \mathrm{H}), 2.56(\mathrm{~s}, 6 \mathrm{H}), 2.50(\mathrm{~s}, 6 \mathrm{H}), 1.99-1.90(\mathrm{~m}, 2 \mathrm{H}) ;{ }^{13} \mathrm{C}-\mathrm{NMR}(101$ $\mathrm{MHz}, \mathrm{CDCl} 3) \delta: 165.57,154.09,151.29,147.80,139.09,36.89,29.87,22.94,22.07,21.47$; HRMS (ESI) $\mathrm{m} / z$ : $371.2189[\mathrm{M}+\mathrm{H}]^{+}$, calcd. for $\left[\mathrm{C}_{19} \mathrm{H}_{27} \mathrm{~N}_{6} \mathrm{O}_{2}\right]^{+} 371.2195$.

\subsection{2. $\mathrm{N}, \mathrm{N}^{\prime}$-(Butane-1,4-Diyl)Bis(3,5,6-Trimethylpyrazine-2-Carboxamide) (8b)}

Pale white solid, yield 30\%, m.p. 168.4-168.6 ${ }^{\circ} \mathrm{C} ;{ }^{1} \mathrm{H}-\mathrm{NMR}\left(300 \mathrm{MHz}, \mathrm{CDCl}_{3}\right) \delta: 8.07(\mathrm{t}, J=5.5 \mathrm{~Hz}$, 2H), 3.50-3.48 (m, 4H), $2.91(\mathrm{~s}, 6 \mathrm{H}), 2.56(\mathrm{~s}, 6 \mathrm{H}), 2.52(\mathrm{~s}, 6 \mathrm{H}), 1.75-1.73(\mathrm{~m}, 4 \mathrm{H}) ;{ }^{13} \mathrm{C}-\mathrm{NMR}(101 \mathrm{MHz}$, $\mathrm{CDCl}_{3}$ ) $\delta: 165.25,154.15,151.38,147.75,139.07,50.90,39.13,27.49,22.96,22.06,21.48$; HRMS (ESI) $\mathrm{m} / z$ : $385.2352[\mathrm{M}+\mathrm{H}]^{+}$, calcd. for $\left[\mathrm{C}_{20} \mathrm{H}_{29} \mathrm{~N}_{6} \mathrm{O}_{2}\right]^{+}$385.2352. 


\subsubsection{N,N'-(Hexane-1,6-Diyl)Bis(3,5,6-Trimethylpyrazine-2-Carboxamide) (8c)}

Pale white solid, yield $47 \%$, m.p. $114.2-114.7^{\circ} \mathrm{C} ;{ }^{1} \mathrm{H}-\mathrm{NMR}\left(300 \mathrm{MHz}, \mathrm{CDCl}_{3}\right) \delta: 8.02(\mathrm{t}, J=5.4$ $\mathrm{Hz}, 2 \mathrm{H}), 3.45-3.38(\mathrm{~m}, 4 \mathrm{H}), 2.90(\mathrm{~s}, 6 \mathrm{H}), 2.55(\mathrm{~s}, 6 \mathrm{H}), 2.51(\mathrm{~s}, 6 \mathrm{H}), 1.67-1.63(\mathrm{~m}, 4 \mathrm{H}), 1.47-1.43(\mathrm{~m}, 4 \mathrm{H})$; ${ }^{13} \mathrm{C}-\mathrm{NMR}\left(101 \mathrm{MHz}, \mathrm{CDCl}_{3}\right.$ ) $\delta: 165.12,154.03,151.35,147.63,139.11,39.33,29.74,26.82,22.98,22.06$, 21.48; HRMS (ESI) $m / z: 413.2662[\mathrm{M}+\mathrm{H}]^{+}$, calcd. for $\left[\mathrm{C}_{22} \mathrm{H}_{33} \mathrm{~N}_{6} \mathrm{O}_{2}\right]^{+} 413.2665$.

\subsubsection{N,N'-(Octane-1,8-Diyl)Bis(3,5,6-Trimethylpyrazine-2-Carboxamide) (8d)}

Pale white solid, yield 68\%, m.p. 113.6-113.8 ${ }^{\circ} \mathrm{C} ;{ }^{1} \mathrm{H}-\mathrm{NMR}\left(300 \mathrm{MHz}, \mathrm{CDCl}_{3}\right) \delta: 8(\mathrm{t}, J=5.3 \mathrm{~Hz}$, 2H), 3.45-3.38 (m, 4H), $2.91(\mathrm{~s}, 6 \mathrm{H}), 2.56(\mathrm{~s}, 6 \mathrm{H}), 2.52(\mathrm{~s}, 6 \mathrm{H}), 1.65-1.60(\mathrm{~m}, 4 \mathrm{H}), 1.37-1.37(\mathrm{~m}, 8 \mathrm{H})$; ${ }^{13} \mathrm{C}-\mathrm{NMR}\left(101 \mathrm{MHz}, \mathrm{CDCl}_{3}\right) \delta: 165.10,154.02,151.40,147.65,139.20,39.45,29.81,29.34,27.11,23.01$, 22.08, 21.53; HRMS (ESI) $m / z: 441.2975[\mathrm{M}+\mathrm{H}]^{+}$, calcd. for $\left[\mathrm{C}_{24} \mathrm{H}_{37} \mathrm{~N}_{6} \mathrm{O}_{2}\right]^{+} 441.2978$.

\subsubsection{N,N'-(Decane-1,10-Diyl)Bis(3,5,6-Trimethylpyrazine-2-Carboxamide) (8e)}

Pale white solid, yield $66 \%$, m.p. $110.3-110.6{ }^{\circ} \mathrm{C} ;{ }^{1} \mathrm{H}-\mathrm{NMR}\left(300 \mathrm{MHz}, \mathrm{CDCl}_{3}\right) \delta: 8(\mathrm{t}, J=5.2 \mathrm{~Hz}$, $2 \mathrm{H}), 3.44-3.37(\mathrm{~m}, 4 \mathrm{H}), 2.91(\mathrm{~s}, 6 \mathrm{H}), 2.55(\mathrm{~s}, 6 \mathrm{H}), 2.51(\mathrm{~s}, 6 \mathrm{H}), 1.64-1.57(\mathrm{~m}, 4 \mathrm{H}), 1.34-1.30(\mathrm{~m}, 12 \mathrm{H})$; ${ }^{13} \mathrm{C}-\mathrm{NMR}\left(101 \mathrm{MHz}, \mathrm{CDCl}_{3}\right) \delta:$ 165.07, 153.97, 151.33, 147.66, 139.21, 39.47, 29.80, 29.56, 29.39, 27.14, 22.94, 22.02, 21.49; HRMS (ESI) $m / z: 469.3287[\mathrm{M}+\mathrm{H}]^{+}$, calcd. for $\left[\mathrm{C}_{26} \mathrm{H}_{41} \mathrm{~N}_{6} \mathrm{O}_{2}\right]^{+} 469.3291$.

\subsubsection{N,N'-(Dodecane-1,12-Diyl)Bis(3,5,6-Trimethylpyrazine-2-Carboxamide) (8f)}

Pale white solid, yield 72\%, m.p. 98.3-99.1 ${ }^{\circ} \mathrm{C} ;{ }^{1} \mathrm{H}-\mathrm{NMR}\left(300 \mathrm{MHz}, \mathrm{CDCl}_{3}\right) \delta: 8(\mathrm{t}, J=4.9 \mathrm{~Hz}, 2 \mathrm{H})$, 3.45-3.38 (m, 4H), $2.91(\mathrm{~s}, 6 \mathrm{H}), 2.56(\mathrm{~s}, 6 \mathrm{H}), 2.52(\mathrm{~s}, 6 \mathrm{H}), 1.67-1.57(\mathrm{~m}, 4 \mathrm{H}), 1.34-1.27(\mathrm{~m}, 16 \mathrm{H}) ;{ }^{13} \mathrm{C}-\mathrm{NMR}$ $\left(101 \mathrm{MHz}, \mathrm{CDCl}_{3}\right) \delta:$ 165.07, 153.98, 151.37, 147.62, 139.22, 39.49, 29.83, 29.66, 29.44, 27.18, 22.99, 22.07, 21.51; HRMS (ESI) $m / z: 497.3602[\mathrm{M}+\mathrm{H}]^{+}$, calcd. for $\left[\mathrm{C}_{28} \mathrm{H}_{45} \mathrm{~N}_{6} \mathrm{O}_{2}\right]^{+} 497.3604$.

\subsection{General Synthetic Procedure for $\mathbf{9 e - 3 5 e}$}

Compounds $9 \mathbf{e}-\mathbf{3 5 e}$ were obtained by using one-pot reaction. A mixture of aromatic acid (6.30 $\mathrm{mmol}), \mathrm{EDCI}(7.50 \mathrm{mmol}), \mathrm{DMAP}(0.60 \mathrm{mmol})$, and anhydrous dichloromethane $(20 \mathrm{~mL})$ was stirred to dissolve, then decane-diamine ( $3 \mathrm{mmol}$ ) was added and stirred at room temperature for $12 \mathrm{~h}$. The mixture solution was filtered under reduced pressure. After that, the residue was washed with little amount of $\mathrm{CH}_{2} \mathrm{Cl}_{2}$ and water successively, and dried to give the solid. Then, the residue was purified on preparative TLC eluted with chloroform/methanol $=40: 1-7: 1$ to yield compounds $\mathbf{2 6 e}, \mathbf{2 8 e}, \mathbf{3 0 e}$, and 31e.

\subsection{1. (2E,2'E)-N, $\mathrm{N}^{\prime}$-(Decane-1,10-Diyl)Bis(3-Phenylacrylamide) (9e)}

Pale white solid, yield 62\%, m.p. $169.8-170.5{ }^{\circ} \mathrm{C} ;{ }^{1} \mathrm{H}-\mathrm{NMR}\left(300 \mathrm{MHz}, \mathrm{CDCl}_{3}+\mathrm{CD}_{3} \mathrm{OD}\right) \delta: 7.54$ $(\mathrm{d}, J=15.7 \mathrm{~Hz}, 2 \mathrm{H}), 7.49-7.46(\mathrm{~m}, 4 \mathrm{H}), 7.36-7.31(\mathrm{~m}, 6 \mathrm{H}), 6.47(\mathrm{~d}, J=15.6 \mathrm{~Hz}, 2 \mathrm{H}), 3.33-3.28(\mathrm{~m}, 4 \mathrm{H})$, 1.57-1.54 (m, 4H), 1.52-1.28 (m, 12H); ${ }^{13} \mathrm{C}-\mathrm{NMR}\left(101 \mathrm{MHz}, \mathrm{CDCl}_{3}+\mathrm{CD}_{3} \mathrm{OD}\right) \delta: 150.10,149.45,148.78$, $147.76,58.71,54.92,29.73,29.52,27.48,26.57,21.64,21.47,20.74$; HRMS (ESI) $\mathrm{m} / z: 433.2851[\mathrm{M}+\mathrm{H}]^{+}$, calcd. for $\left[\mathrm{C}_{28} \mathrm{H}_{45} \mathrm{~N}_{6} \mathrm{O}_{2}\right]^{+} 433.2855$

\subsubsection{N,N'-(Decane-1,10-Diyl)Dinicotinamide (10e)}

Pale white solid, yield 67\%, m.p. $167.4-167.8^{\circ} \mathrm{C} ;{ }^{1} \mathrm{H}-\mathrm{NMR}\left(300 \mathrm{MHz}, \mathrm{CDCl}_{3}+\mathrm{CD}_{3} \mathrm{OD}\right) \delta: 8.84$ (s, $2 \mathrm{H}), 8.55(\mathrm{~d}, J=3.9 \mathrm{~Hz}, 2 \mathrm{H}), 8.11(\mathrm{dt}, J=8,1.7 \mathrm{~Hz}, 2 \mathrm{H}), 7.35(\mathrm{dd}, J=7.9,4.9 \mathrm{~Hz}, 2 \mathrm{H}), 3.34(\mathrm{t}, J=7.2 \mathrm{~Hz}$, $4 \mathrm{H}), 1.58-1.51(\mathrm{~m}, 4 \mathrm{H}), 1.27-1.24(\mathrm{~m}, 12 \mathrm{H}) ;{ }^{13} \mathrm{C}-\mathrm{NMR}\left(101 \mathrm{MHz}, \mathrm{CDCl}_{3}+\mathrm{CD}_{3} \mathrm{OD}\right) \delta: 165.85,151.29$, 147.53, 135.93, 130.87, 123.79, 40.16, 29.28, 29.12, 26.86; HRMS (ESI) $m / z: 383.2441$ [M + H] ${ }^{+}$, calcd. for $\left[\mathrm{C}_{28} \mathrm{H}_{45} \mathrm{~N}_{6} \mathrm{O}_{2}\right]^{+} 383.2447$. 


\subsection{3. $\mathrm{N}, \mathrm{N}^{\prime}$-(Decane-1,10-Diyl)Dibenzamide (11e)}

Pale white solid, yield 70\%, m.p. $154.3-154.6{ }^{\circ} \mathrm{C} ;{ }^{1} \mathrm{H}-\mathrm{NMR}\left(300 \mathrm{MHz}, \mathrm{CDCl}_{3}+\mathrm{CD}_{3} \mathrm{OD}\right) \delta: 7.77-7.73$ $(\mathrm{m}, 4 \mathrm{H}), 7.51-7.33(\mathrm{~m}, 6 \mathrm{H}), 3.42-3.35(\mathrm{~m}, 4 \mathrm{H}), 1.63-1.56(\mathrm{~m}, 4 \mathrm{H}), 1.34-1.30(\mathrm{~m}, 12 \mathrm{H}) ;{ }^{13} \mathrm{C}-\mathrm{NMR}(101$ $\left.\mathrm{MHz}, \mathrm{CDCl}_{3}+\mathrm{CD}_{3} \mathrm{OD}\right) \delta: 168.39,134.55,131.36,128.45,126.86,40.02,29.36,29.27,29.13,26.84$. HRMS (ESI) $m / z: 381.2702[\mathrm{M}+\mathrm{H}]^{+}$, calcd. for $\left[\mathrm{C}_{24} \mathrm{H}_{33} \mathrm{~N}_{2} \mathrm{O}_{2}\right]^{+} 381.2542$.

\subsection{4. $\mathrm{N}, \mathrm{N}^{\prime}$-(Decane-1,10-Diyl)Bis(2-Naphthamide) (12e)}

Pale white solid, yield $64 \%$, m.p. $163.9-164{ }^{\circ} \mathrm{C} ;{ }^{1} \mathrm{H}-\mathrm{NMR}\left(300 \mathrm{MHz}, \mathrm{CDCl}_{3}+\mathrm{CD}_{3} \mathrm{OD}\right) \delta: 8.22-8.17$ (m, 2H), 7.89-7.82 (m, 4H), 7.54-7.39 (m, 8H), 3.49-3.44 (m, 4H), 1.67-1.60 (m, 4H), 1.38-1.34 (m, 12H); ${ }^{13} \mathrm{C}-\mathrm{NMR}\left(101 \mathrm{MHz}, \mathrm{CDCl}_{3}+\mathrm{CD}_{3} \mathrm{OD}\right) \delta: 170.38,134.50,133.56,130.33,129.96,128.22,126.89,126.29$, $125.10,124.77,124.65,39.94,29.36,29.30,29.11,26.85$. HRMS (ESI) $\mathrm{m} / z: 481.2853$ [M + H]+, calcd. for $\left[\mathrm{C}_{32} \mathrm{H}_{37} \mathrm{~N}_{2} \mathrm{O}_{2}\right]^{+} 481.2855$.

\subsubsection{N,N'-(Decane-1,10-Diyl)Diisonicotinamide (13e)}

Pale white solid, yield 60\%, m.p. $175.6-176.3{ }^{\circ} \mathrm{C} ;{ }^{1} \mathrm{H}-\mathrm{NMR}\left(300 \mathrm{MHz}, \mathrm{CDCl}_{3}+\mathrm{CD}_{3} \mathrm{OD}\right) \delta: 8.62(\mathrm{~d}$, $J=5.6 \mathrm{~Hz}, 4 \mathrm{H}), 7.71(\mathrm{dd}, J=6.1,2.8 \mathrm{~Hz}, 4 \mathrm{H}), 3.41-3.33(\mathrm{~m}, 4 \mathrm{H}), 1.64-1.57(\mathrm{~m}, 4 \mathrm{H}), 1.33-1.31(\mathrm{~m}, 12 \mathrm{H})$; ${ }^{13} \mathrm{C}-\mathrm{NMR}\left(101 \mathrm{MHz}, \mathrm{CDCl}_{3}+\mathrm{CD}_{3} \mathrm{OD}\right) \delta: 165.88,149.48,142.45,121.46,40.04,29.16,28.99,26.71$. HRMS (ESI) $m / z: 383.2445[\mathrm{M}+\mathrm{H}]^{+}$, calcd. for $\left[\mathrm{C}_{22} \mathrm{H}_{31} \mathrm{~N}_{4} \mathrm{O}_{2}\right]^{+} 383.2447$.

\subsubsection{N,N'-(Decane-1,10-Diyl)Bis(Furan-2-Carboxamide) (14e)}

Pale white solid, yield $62 \%$, m.p. $132.6-133.3{ }^{\circ} \mathrm{C} ;{ }^{1} \mathrm{H}-\mathrm{NMR}\left(300 \mathrm{MHz}, \mathrm{CDCl}_{3}\right) \delta: 7.41(\mathrm{dd}, J=$ $1.7,0.8 \mathrm{~Hz}, 2 \mathrm{H}), 7.09(\mathrm{dd}, J=3.5,0.7 \mathrm{~Hz}, 2 \mathrm{H}), 6.48(\mathrm{dd}, J=3.5,1.7 \mathrm{~Hz}, 2 \mathrm{H}), 6.37(\mathrm{br}, 2 \mathrm{H}), 3.45-3.38$ $(\mathrm{m}, 4 \mathrm{H}), 1.65-1.55(\mathrm{~m}, 4 \mathrm{H}), 1.36-1.30(\mathrm{~m}, 12 \mathrm{H}) ;{ }^{13} \mathrm{C}-\mathrm{NMR}\left(101 \mathrm{MHz}, \mathrm{CDCl}_{3}\right) \delta: 158.53,148.38,143.77$, $114.02,112.22,39.29,29.80,29.48,29.33,26.98$. HRMS (ESI) $\mathrm{m} / \mathrm{z}: 383.1944[\mathrm{M}+\mathrm{Na}]^{+}$, calcd. for $\left[\mathrm{C}_{20} \mathrm{H}_{28} \mathrm{~N}_{2} \mathrm{NaO}_{4}\right]^{+} 383.1947$.

\subsubsection{N,N'-(Decane-1,10-Diyl)Dipicolinamide (15e)}

Pale white solid, yield 68\%, m.p. $156.6-156.9{ }^{\circ} \mathrm{C} ;{ }^{1} \mathrm{H}-\mathrm{NMR}\left(300 \mathrm{MHz}, \mathrm{CDCl}_{3}\right) \delta: 9.35(\mathrm{~d}, J=1.4$ $\mathrm{Hz}, 2 \mathrm{H}), 8.69(\mathrm{~d}, J=2.5 \mathrm{~Hz}, 2 \mathrm{H}), 8.47-8.46(\mathrm{~m}, 2 \mathrm{H}), 7.77(\mathrm{br}, 2 \mathrm{H}), 3.47-3.40(\mathrm{~m}, 4 \mathrm{H}), 1.65-1.55(\mathrm{~m}, 4 \mathrm{H})$, 1.34-1.26 (m, 12H); ${ }^{13} \mathrm{C}-\mathrm{NMR}\left(101 \mathrm{MHz}, \mathrm{CDCl}_{3}\right) \delta: 163.01,147.26,144.76,144.55,142.58,39.61,29.68$, 29.51, 29.34, 27.03. HRMS (ESI) $m / z: 383.2441[\mathrm{M}+\mathrm{H}]^{+}$, calcd. for $\left[\mathrm{C}_{22} \mathrm{H}_{31} \mathrm{~N}_{4} \mathrm{O}_{2}\right]^{+} 383.2447$

\subsection{8. $\mathrm{N}, \mathrm{N}^{\prime}$-(Decane-1,10-Diyl)Bis(Pyrazine-2-Carboxamide) (16e)}

Pale white solid, yield 70\%, m.p. 77.6-80.1 ${ }^{\circ} \mathrm{C} ;{ }^{1} \mathrm{H}-\mathrm{NMR}\left(300 \mathrm{MHz}, \mathrm{CDCl}_{3}\right) \delta: 8.54-8.51(\mathrm{~m}, 2 \mathrm{H})$, 8.20-8.17 (m, 2H), 8.05 (br, 2H), 7.85-7.80 (m, 2H), 7.42-7.38 (m, 2H), 3.49-3.43 (m, 4H), 1.68-1.58 (m, $4 \mathrm{H}), 1.38-1.26(\mathrm{~m}, 12 \mathrm{H}) ;{ }^{13} \mathrm{C}-\mathrm{NMR}\left(101 \mathrm{MHz}, \mathrm{CDCl}_{3}\right) \delta: 164.31,150.25,148.09,137.49,126.13,122.34$, 39.61, 29.77, 29.56, 29.41, 27.11. HRMS (ESI) $m / z: 385.2350[\mathrm{M}+\mathrm{H}]^{+}$, calcd. for $\left[\mathrm{C}_{20} \mathrm{H}_{29} \mathrm{~N}_{6} \mathrm{O}_{2}\right]^{+} 385.2352$.

\subsubsection{N,N'-(Decane-1,10-Diyl)Bis(Quinoline-3-Carboxamide) (17e)}

Pale white solid, yield 59\%, m.p. 206.7-207. ${ }^{\circ} \mathrm{C} ;{ }^{1} \mathrm{H}-\mathrm{NMR}$ (300 MHz, DMSO- $d_{6}+\mathrm{CD}_{3} \mathrm{OD}$ ) $\delta: 8.57$ $(\mathrm{d}, J=1.8 \mathrm{~Hz}, 2 \mathrm{H}), 8.09(\mathrm{~s}, 2 \mathrm{H}), 7.39(\mathrm{dd}, J=8.3,3.1 \mathrm{~Hz}, 4 \mathrm{H}), 7.17(\mathrm{t}, J=7.6 \mathrm{~Hz}, 2 \mathrm{H}), 7(\mathrm{t}, J=7.4 \mathrm{~Hz}, 2 \mathrm{H})$, $2.68(\mathrm{t}, J=7 \mathrm{~Hz}, 4 \mathrm{H}), 0.99-0.88(\mathrm{~m}, 4 \mathrm{H}), 0.76-0.62(\mathrm{~m}, 12 \mathrm{H}) .{ }^{13} \mathrm{C}-\mathrm{NMR}\left(101 \mathrm{MHz}, \mathrm{CDCl}_{3}\right) \delta: 165.92$, $148.01,136.52,131.47,128.81,127.93,127.56,127.35,127.06,40.11,29.20,29.15,29.04,26.78$. HRMS (ESI) $m / z: 483.2756[\mathrm{M}+\mathrm{H}]^{+}$, calcd. for $\left[\mathrm{C}_{30} \mathrm{H}_{35} \mathrm{~N}_{4} \mathrm{O}_{2}\right]^{+} 483.2760$.

\subsubsection{0. $\mathrm{N}, \mathrm{N}^{\prime}$-(Decane-1,10-Diyl)Bis(Quinoline-6-Carboxamide) (18e)}

Pale yellow solid, yield 73\%, m.p. $197.7-198.3{ }^{\circ} \mathrm{C} ;{ }^{1} \mathrm{H}-\mathrm{NMR}\left(300 \mathrm{MHz}, \mathrm{CDCl}_{3}+\mathrm{CD}_{3} \mathrm{OD}\right) \delta: 8.71$ $(\mathrm{dd}, J=4.3,1.6 \mathrm{~Hz}, 2 \mathrm{H}), 8.19(\mathrm{~d}, J=1.6 \mathrm{~Hz}, 2 \mathrm{H}), 8.16(\mathrm{dd}, J=8.3,1.3 \mathrm{~Hz}, 2 \mathrm{H}), 7.95(\mathrm{dd}, J=8.8,1.9$ $\mathrm{Hz}, 2 \mathrm{H}), 7.91(\mathrm{~s}, 2 \mathrm{H}), 7.35(\mathrm{dd}, J=8.3,4.3 \mathrm{~Hz}, 2 \mathrm{H}), 3.28(\mathrm{t}, J=7.2 \mathrm{~Hz}, 4 \mathrm{H}), 1.53-1.45(\mathrm{~m}, 5 \mathrm{H}), 1.22-1.13$ 
(m, 12H). ${ }^{13} \mathrm{C}-\mathrm{NMR}\left(101 \mathrm{MHz}, \mathrm{CDCl}_{3}+\mathrm{CD}_{3} \mathrm{OD}\right) \delta: 167.43,151.15,148.21,137.99,132.82,128.38$, $127.79,127.71,127.64,121.81,40.14,29.19,29.04,26.78$. HRMS (ESI) $m / z: 483.2758[\mathrm{M}+\mathrm{H}]^{+}$, calcd. for $\left[\mathrm{C}_{30} \mathrm{H}_{35} \mathrm{~N}_{4} \mathrm{O}_{2}\right]^{+} 483.2760$.

\subsubsection{N,N'-(Decane-1,10-Diyl)Bis(1H-Benzo[d]Imidazole-6-Carboxamide) (19e)}

Brick red solid, yield 75\%, m.p. 229.7-230.3 ${ }^{\circ} \mathrm{C} ;{ }^{1} \mathrm{H}-\mathrm{NMR}\left(300 \mathrm{MHz}, \mathrm{CDCl}_{3}+\mathrm{CD}_{3} \mathrm{OD}\right) \delta: 8.11$ (s, 2H), $8.07(\mathrm{~s}, 2 \mathrm{H}), 7.73(\mathrm{dd}, J=8.5,1.6 \mathrm{~Hz}, 2 \mathrm{H}), 7.61(\mathrm{~d}, J=8.5 \mathrm{~Hz}, 2 \mathrm{H}), 3.42(\mathrm{t}, J=7.1 \mathrm{~Hz}, 4 \mathrm{H})$, $1.70-1.56(\mathrm{~m}, 4 \mathrm{H}), 1.42-1.25(\mathrm{~m}, 12 \mathrm{H}) .{ }^{13} \mathrm{C}-\mathrm{NMR}\left(101 \mathrm{MHz}, \mathrm{CDCl}_{3}+\mathrm{CD}_{3} \mathrm{OD}\right) \delta: 168.61,142.46,128.70$, $121.15,39.32,28.66,28.62,28.50,26.19$. HRMS (ESI) $m / z: 461.2662[\mathrm{M}+\mathrm{H}]^{+}$, calcd. for $\left[\mathrm{C}_{26} \mathrm{H}_{33} \mathrm{~N}_{6} \mathrm{O}_{2}\right]^{+}$ 461.2665 .

4.6.12. $\mathrm{N}, \mathrm{N}^{\prime}$-(Decane-1,10-Diyl)Bis(2-Oxo-2H-Chromene-3-Carboxamide) (20e)

Pale white solid, yield 60\%, m.p. 208.9-209. ${ }^{\circ} \mathrm{C}^{\circ}{ }^{1} \mathrm{H}-\mathrm{NMR}\left(300 \mathrm{MHz}, \mathrm{CDCl}_{3}\right) \delta: 8.90$ (s, 2H), 8.80 (s, 2H), 7.71-7.61 (m, 4H), 7.43-7.32 (m, 4H), $3.45(\mathrm{dd}, J=13,7 \mathrm{~Hz}, 4 \mathrm{H}), 1.63(\mathrm{dt}, J=14.4,7.2 \mathrm{~Hz}, 4 \mathrm{H})$, 1.44-1.26 (m, 12H). ${ }^{13} \mathrm{C}-\mathrm{NMR}\left(101 \mathrm{MHz}, \mathrm{CDCl}_{3}+\mathrm{CD}_{3} \mathrm{OD}\right) \delta: 161.74,161.44,154.23,148.38,134.16$, $129.80,125.30,118.46,117.97,116.38,39.69,29.20,29.02,29.01,26.77$. HRMS (ESI) $m / z: 517.2338[\mathrm{M}+$ $\mathrm{H}]^{+}$, calcd. for $\left[\mathrm{C}_{30} \mathrm{H}_{33} \mathrm{~N}_{2} \mathrm{O}_{6}\right]^{+}$517.2339.

\subsubsection{N,N'-(Decane-1,10-Diyl)Bis(Benzofuran-2-Carboxamide) (21e)}

Pale white solid, yield $43 \%$, m.p. $135.8-136.3{ }^{\circ} \mathrm{C} ;{ }^{1} \mathrm{H}-\mathrm{NMR}\left(300 \mathrm{MHz}, \mathrm{DMSO}-d_{6}\right) \delta: 8.64(\mathrm{~s}, 2 \mathrm{H})$, $7.74(\mathrm{~d}, J=7.7 \mathrm{~Hz}, 2 \mathrm{H}), 7.62(\mathrm{~d}, J=8.2 \mathrm{~Hz}, 2 \mathrm{H}), 7.49(\mathrm{~s}, 2 \mathrm{H}), 7.43(\mathrm{t}, J=7.5 \mathrm{~Hz}, 2 \mathrm{H}), 7.30(\mathrm{t}, J=7.4$ $\mathrm{Hz}, 2 \mathrm{H}), 3.25(\mathrm{dd}, J=13.1,6.6 \mathrm{~Hz}, 4 \mathrm{H}), 1.58-1.43(\mathrm{~m}, 4 \mathrm{H}), 1.37-1.14(\mathrm{~m}, 12 \mathrm{H}) .{ }^{13} \mathrm{C}-\mathrm{NMR}(101 \mathrm{MHz}$, DMSO- $\left.d_{6}\right) \delta: 157.94,154.13,149.37,127.17,126.61,123.59,122.63,111.70,109.02,38.68,29.01,28.91$, 28.71, 26.39. HRMS (ESI) $m / z: 461.2438[\mathrm{M}+\mathrm{H}]^{+}$, calcd. for $\left[\mathrm{C}_{28} \mathrm{H}_{33} \mathrm{~N}_{2} \mathrm{O}_{4}\right]^{+} 461.2430$.

\subsubsection{4. $\mathrm{N}, \mathrm{N}^{\prime}$-(Decane-1,10-Diyl)Bis(Benzo[b]Thiophene-2-Carboxamide) (22e)}

Pale yellow solid, yield $46 \%$, m.p. $175-175.7{ }^{\circ} \mathrm{C} ;{ }^{1} \mathrm{H}-\mathrm{NMR}\left(300 \mathrm{MHz}, \mathrm{DMSO}-d_{6}\right) \delta: 8.68(\mathrm{~s}, 2 \mathrm{H})$, $8.04(\mathrm{~s}, 2 \mathrm{H}), 8.01-7.95(\mathrm{~m}, 2 \mathrm{H}), 7.93-7.87(\mathrm{~m}, 2 \mathrm{H}), 7.41(\mathrm{p}, J=7 \mathrm{~Hz}, 4 \mathrm{H}), 3.25(\mathrm{dd}, J=12.8,6.6 \mathrm{~Hz}, 4 \mathrm{H})$, $1.58-1.44(\mathrm{~m}, 4 \mathrm{H}), 1.37-1.21(\mathrm{~m}, 12 \mathrm{H}) .{ }^{13} \mathrm{C}-\mathrm{NMR}\left(101 \mathrm{MHz}, \mathrm{DMSO}-d_{6}\right) \delta: 161.28,140.28,140.07,139.16$, $126,125.02,124.80,124.33,122.72,28.99,28.92,28.72,26.43$. HRMS (ESI) $m / z: 493.1976[\mathrm{M}+\mathrm{H}]^{+}$, calcd. for $\left[\mathrm{C}_{28} \mathrm{H}_{33} \mathrm{~N}_{2} \mathrm{O}_{2} \mathrm{~S}_{2}\right]^{+} 493.1983$.

\subsubsection{N,N'-(Decane-1,10-Diyl)Bis(1-Methyl-1H-Indole-3-Carboxamide) (23e)}

Pale white solid, yield $43 \%$, m.p. $192.8-193.2{ }^{\circ} \mathrm{C} ;{ }^{1} \mathrm{H}-\mathrm{NMR}$ (300 MHz, DMSO- $\left.d_{6}+\mathrm{CD}_{3} \mathrm{OD}\right) \delta: 8.08$ $(\mathrm{d}, J=7.7 \mathrm{~Hz}, 2 \mathrm{H}), 7.86(\mathrm{~s}, 2 \mathrm{H}), 7.41(\mathrm{~d}, J=8 \mathrm{~Hz}, 2 \mathrm{H}), 7.20-7.13(\mathrm{~m}, 2 \mathrm{H}), 7.13-7.06(\mathrm{~m}, 2 \mathrm{H}), 3.78(\mathrm{~s}, 6 \mathrm{H})$, $3.22(\mathrm{t}, J=7.1 \mathrm{~Hz}, 4 \mathrm{H}), 1.55-1.43(\mathrm{~m}, 4 \mathrm{H}), 1.32-1.22(\mathrm{~m}, 12 \mathrm{H}) .{ }^{13} \mathrm{C}-\mathrm{NMR}\left(101 \mathrm{MHz}, \mathrm{CDCl}_{3}+\mathrm{CD}_{3} \mathrm{OD}\right)$ $\delta:$ 166.26, 137.01, 131.75, 125.56, 122.27, 121.03, 120.13, 109.63, 39.26, 32.62, 29.33, 29.07, 28.94, 26.66. HRMS (ESI) $m / z: 487.3064[\mathrm{M}+\mathrm{H}]^{+}$, calcd. for $\left[\mathrm{C}_{30} \mathrm{H}_{39} \mathrm{~N}_{4} \mathrm{O}_{2}\right]^{+} 487.3073$.

4.6.16. N,N'-(Decane-1,10-Diyl)Bis(1H-Indole-6-Carboxamide) (24e)

Pale white solid, yield $47 \%$, m.p. $168.4-169.2{ }^{\circ} \mathrm{C} ;{ }^{1} \mathrm{H}-\mathrm{NMR}\left(300 \mathrm{MHz}\right.$, DMSO- $\left.d_{6}\right) \delta: 11.32(\mathrm{~s}, 2 \mathrm{H})$, $8.30(\mathrm{~s}, 2 \mathrm{H}), 7.92(\mathrm{~s}, 2 \mathrm{H}), 7.59-7.41(\mathrm{~m}, 6 \mathrm{H}), 6.46(\mathrm{~s}, 2 \mathrm{H}), 3.25(\mathrm{dd}, J=12.7,6.4 \mathrm{~Hz}, 4 \mathrm{H}), 1.61-1.43(\mathrm{~m}$, $4 \mathrm{H}), 1.38-1.21$ (m, 12H). ${ }^{13} \mathrm{C}-\mathrm{NMR}(101 \mathrm{MHz}, \mathrm{DMSO}) \delta: 167.04,135.24,129.61,127.74,127.66,119.27$, $117.90,111.07,101.14,39.21,29.27,29,28.83,26.55$. HRMS (ESI) $\mathrm{m} / z: 459.2760[\mathrm{M}+\mathrm{H}]^{+}$, calcd. for $\left[\mathrm{C}_{28} \mathrm{H}_{35} \mathrm{~N}_{4} \mathrm{O}_{2}\right]^{+} 459.2760$.

\subsubsection{7. (2E,2'E)-N, $\mathrm{N}^{\prime}$-(Decane-1,10-Diyl)Bis(3-(4-Chlorophenyl)Acrylamide) (25e)}

Pale white solid, yield 64\%, m.p. 230.3-230.9 ${ }^{\circ} \mathrm{C} ;{ }^{1} \mathrm{H}-\mathrm{NMR}\left(300 \mathrm{MHz}, \mathrm{CDCl}_{3}+\mathrm{CF}_{3} \mathrm{COOD}\right) \delta: 7.64$ $(\mathrm{d}, J=13 \mathrm{~Hz}, 2 \mathrm{H}), 7.54-7.38(\mathrm{~m}, 8 \mathrm{H}), 6.51(\mathrm{~d}, J=11.9 \mathrm{~Hz}, 2 \mathrm{H}), 3.62-3.37(\mathrm{~m}, 4 \mathrm{H}), 1.73-1.54(\mathrm{~m}, 4 \mathrm{H})$, 
1.46-1.18 (m, 12H). ${ }^{13} \mathrm{C}-\mathrm{NMR}\left(101 \mathrm{MHz}, \mathrm{CDCl}_{3}+\mathrm{CF}_{3} \mathrm{COOD}\right) \delta: 129.71,118.78,115.96,113.13,110.30$, 29.22, 28.99, 26.64. HRMS (ESI) $m / z: 501.2075[\mathrm{M}+\mathrm{H}]^{+}$, calcd. for $\left[\mathrm{C}_{28} \mathrm{H}_{35} \mathrm{Cl}_{2} \mathrm{~N}_{2} \mathrm{O}_{2}\right]^{+}$501.2076.

4.6.18. (2E,2'E)-N,N'-(Decane-1,10-Diyl)Bis(3-(3-Hydroxy-4-Methoxyphenyl)Acrylamide) (26e)

Pale yellow solid, yield 35\%, m.p. $192.9-195.3{ }^{\circ} \mathrm{C} ;{ }^{1} \mathrm{H}-\mathrm{NMR}\left(300 \mathrm{MHz}, \mathrm{CDCl}_{3}+\mathrm{CD}_{3} \mathrm{OD}\right) \delta: 7.42$ $(\mathrm{d}, J=15.3 \mathrm{~Hz}, 2 \mathrm{H}), 7.05(\mathrm{~s}, 2 \mathrm{H}), 6.98(\mathrm{~d}, J=8.1 \mathrm{~Hz}, 2 \mathrm{H}), 6.83(\mathrm{~d}, J=8.3 \mathrm{~Hz}, 2 \mathrm{H}), 6.33(\mathrm{~d}, J=15.6 \mathrm{~Hz}$, 2H), $3.89(\mathrm{~s}, 6 \mathrm{H}), 3.29$ (t, $J=7 \mathrm{~Hz}, 4 \mathrm{H}), 1.55-1.50(\mathrm{~m}, 4 \mathrm{H}), 1.31-1.27(\mathrm{~m}, 12 \mathrm{H}) .{ }^{13} \mathrm{C}-\mathrm{NMR}(101 \mathrm{MHz}$, $\left.\mathrm{CDCl}_{3}+\mathrm{CD}_{3} \mathrm{OD}\right) \delta: 167.37,148.94,146.05,140.42,128.11,121.06,118.25,113.07,111,55.57,39.50,29.13$, 28.98, 26.69. HRMS (ESI) $m / z: 525.2951[\mathrm{M}+\mathrm{H}]^{+}$, calcd. for $\left[\mathrm{C}_{30} \mathrm{H}_{41} \mathrm{~N}_{2} \mathrm{O}_{6}\right]^{+} 525.2965$.

4.6.19. (2E,2'E)-N, $\mathrm{N}^{\prime}$-(Decane-1,10-Diyl)Bis(3-(3,4-Dimethoxyphenyl)Acrylamide) (27e)

Pale white solid, yield 59\%, m.p. 168.9-169.9 ${ }^{\circ} \mathrm{C} ;{ }^{1} \mathrm{H}-\mathrm{NMR}\left(300 \mathrm{MHz}, \mathrm{DMSO}-\mathrm{d}_{6}\right) \delta: 7.95$ (br, 2H), 7.30 (br, 2H), 7.11 (br, 4H), 6.97 (br, 2H), 6.50 (br, 2H), 3.78 (br, 12H), $3.14(\mathrm{br}, 4 \mathrm{H}), 1.42$ (br, 4H), 1.27 (br, 12H). ${ }^{13} \mathrm{C}-\mathrm{NMR}\left(101 \mathrm{MHz}, \mathrm{CDCl}_{3}+\mathrm{CD}_{3} \mathrm{OD}\right) \delta: 167.15,150.31,148.90,140.25,127.89,121.77,118.56$, $111.04,109.74,55.66,55.58,39.47,29.16,29.14,28.99,26.69$. HRMS (ESI) $m / z: 553.3272[\mathrm{M}+\mathrm{H}]^{+}$, calcd. for $\left[\mathrm{C}_{32} \mathrm{H}_{45} \mathrm{~N}_{2} \mathrm{O}_{6}\right]^{+} 553.3278$.

4.6.20. (2E,2'E)-N,N'-(Decane-1,10-Diyl)Bis(3-(4-Hydroxy-3,5-Dimethoxyphenyl)Acrylamide) (28e)

Pale yellow solid, yield 33\%, m.p. $179.8-180.5^{\circ} \mathrm{C} ;{ }^{1} \mathrm{H}-\mathrm{NMR}\left(300 \mathrm{MHz}, \mathrm{CDCl}_{3}+\mathrm{CD}_{3} \mathrm{OD}\right.$ ) $\delta: 7.44$ $(\mathrm{d}, J=15.5 \mathrm{~Hz}, 3 \mathrm{H}), 6.76(\mathrm{~s}, 4 \mathrm{H}), 6.37(\mathrm{~d}, J=15.6 \mathrm{~Hz}, 2 \mathrm{H}), 3.88(\mathrm{~s}, 12 \mathrm{H}), 3.30(\mathrm{t}, J=7.1 \mathrm{~Hz}, 4 \mathrm{H}), 1.61-1.49$ $(\mathrm{m}, 4 \mathrm{H}), 1.38-1.24(\mathrm{~m}, 12 \mathrm{H}) .{ }^{13} \mathrm{C}-\mathrm{NMR}\left(101 \mathrm{MHz}, \mathrm{CDCl}_{3}+\mathrm{CD}_{3} \mathrm{OD}\right) \delta: 166.94,147.48,141.03,136.87$, $126.16,118.46,104.99,56.23,39.63,29.39,29.21,29.08,26.79$. HRMS (ESI) $m / z: 585.3164[\mathrm{M}+\mathrm{H}]^{+}$, calcd. for $\left[\mathrm{C}_{32} \mathrm{H}_{45} \mathrm{~N}_{2} \mathrm{O}_{8}\right]^{+} 585.3176$

\subsubsection{1. (2E,2'E)-N, $\mathrm{N}^{\prime}$-(Decane-1,10-Diyl)Bis(3-(3,4,5-Trimethoxyphenyl)Acrylamide) (29e)}

Pale white solid, yield 67\%, m.p. 193.4-194.3 ${ }^{\circ} \mathrm{C} ;{ }^{1} \mathrm{H}-\mathrm{NMR}\left(300 \mathrm{MHz}, \mathrm{CDCl}_{3}+\mathrm{CD}_{3} \mathrm{OD}\right) \delta: 7.45$ (d, $J=15.4 \mathrm{~Hz}, 2 \mathrm{H}), 6.76(\mathrm{~s}, 4 \mathrm{H}), 6.44(\mathrm{~d}, J=15.6 \mathrm{~Hz}, 2 \mathrm{H}), 3.88(\mathrm{~s}, 12 \mathrm{H}), 3.85(\mathrm{~s}, 6 \mathrm{H}), 3.31(\mathrm{t}, J=7.1 \mathrm{~Hz}, 4 \mathrm{H})$, 1.63-1.47 (m, 4H), 1.40-1.23 (m, 12H). ${ }^{13} \mathrm{C}-\mathrm{NMR}\left(101 \mathrm{MHz}, \mathrm{CDCl}_{3}+\mathrm{CD}_{3} \mathrm{OD}\right) \delta: 166.73,153.26,140.53$, $139.33,130.65,120.18,104.99,60.81,56,39.63,29.28,29.21,29.05,26.76$. HRMS (ESI) $m / z: 613.3472[\mathrm{M}+$ $\mathrm{H}]^{+}$, calcd. for $\left[\mathrm{C}_{34} \mathrm{H}_{49} \mathrm{~N}_{2} \mathrm{O}_{8}\right]^{+} 613.3489$.

4.6.22. $\mathrm{N}, \mathrm{N}^{\prime}$-(Decane-1,10-Diyl)Bis(2-Aminobenzamide) (30e)

Pale white solid, yield 67\%, m.p. 90.2-91 ${ }^{\circ} \mathrm{C} ;{ }^{1} \mathrm{H}-\mathrm{NMR}\left(300 \mathrm{MHz}, \mathrm{CDCl}_{3}+\mathrm{CD}_{3} \mathrm{OD}\right) \delta: 7.36$ $(\mathrm{dd}, J=7.8,1.2 \mathrm{~Hz}, 2 \mathrm{H}), 7.22-7.15(\mathrm{~m}, 2 \mathrm{H}), 6.79-6.60(\mathrm{~m}, 4 \mathrm{H}), 3.35(\mathrm{dt}, J=9.7,5.5 \mathrm{~Hz}, 4 \mathrm{H}), 1.66-1.49$ (m, 4H), 1.41-1.24 (m, 12H). ${ }^{13} \mathrm{C}-\mathrm{NMR}\left(101 \mathrm{MHz}, \mathrm{CDCl}_{3}+\mathrm{CD}_{3} \mathrm{OD}\right) \delta: 173.92,151.77,135.96,131.40$, $121.48,121.28,120.96,43.54,33.31,33.26,33.11,30.83$. HRMS (ESI) $m / z: 411.2759[\mathrm{M}+\mathrm{H}]^{+}$, calcd. for $\left[\mathrm{C}_{24} \mathrm{H}_{35} \mathrm{~N}_{4} \mathrm{O}_{2}\right]^{+} 411.2760$.

4.6.23. $\mathrm{N}, \mathrm{N}^{\prime}$-(Decane-1,10-Diyl)Bis(4-Aminobenzamide) (31e)

Pale yellow solid, yield 31\%, m.p. $186.7-187 .{ }^{\circ} \mathrm{C} ;{ }^{1} \mathrm{H}-\mathrm{NMR}\left(300 \mathrm{MHz}, \mathrm{CDCl}_{3}+\mathrm{CD}_{3} \mathrm{OD}\right) \delta: 7.57$ $(\mathrm{d}, J=8.6 \mathrm{~Hz}, 4 \mathrm{H}), 6.66(\mathrm{~d}, J=8.6 \mathrm{~Hz}, 4 \mathrm{H}), 3.34(\mathrm{t}, J=7.2 \mathrm{~Hz}, 4 \mathrm{H}), 1.63-1.53(\mathrm{~m}, 4 \mathrm{H}), 1.31-1.26(\mathrm{~m}$, 12H). ${ }^{13} \mathrm{C}-\mathrm{NMR}\left(101 \mathrm{MHz}, \mathrm{CDCl}_{3}+\mathrm{CD}_{3} \mathrm{OD}\right) \delta: 168.44,150.01,128.49,123.39,114.04,39.77,29.33,29.18$, 29.06, 26.76. HRMS (ESI) $m / z: 411.2755[\mathrm{M}+\mathrm{H}]^{+}$, calcd. for $\left[\mathrm{C}_{24} \mathrm{H}_{35} \mathrm{~N}_{4} \mathrm{O}_{2}\right]^{+} 411.2760$.

4.6.24. $\mathrm{N}, \mathrm{N}^{\prime}$-(Decane-1,10-Diyl)bis(3-Aminobenzamide) (32e)

Pale white solid, yield 57\%, m.p. $135.7-136.3{ }^{\circ} \mathrm{C} ;{ }^{1} \mathrm{H}-\mathrm{NMR}\left(300 \mathrm{MHz}, \mathrm{CDCl}_{3}+\mathrm{CD}_{3} \mathrm{OD}\right) \delta$ : 7.30-6.97 (m, 6H), $6.83(\mathrm{dd}, J=20.8,7.2 \mathrm{~Hz}, 2 \mathrm{H}), 3.36(\mathrm{t}, J=6.8 \mathrm{~Hz}, 4 \mathrm{H}), 1.67-1.47(\mathrm{~m}, 4 \mathrm{H}), 1.46-1.06(\mathrm{~m}$, $12 \mathrm{H}) .{ }^{13} \mathrm{C}-\mathrm{NMR}\left(101 \mathrm{MHz}, \mathrm{CDCl}_{3}+\mathrm{CD}_{3} \mathrm{OD}\right) \delta: 168.75,146.84,135.56,129.27,118.09,116.55,113.73$, 
$77.48,77.16,76.84,49.31,49.09,48.88,48.67,48.45,39.93,29.29,29.22,29.09,26.79$. HRMS (ESI) $\mathrm{m} / z$ : $411.2758[\mathrm{M}+\mathrm{H}]^{+}$, calcd. for $\left[\mathrm{C}_{24} \mathrm{H}_{35} \mathrm{~N}_{4} \mathrm{O}_{2}\right]^{+} 411.2760$

4.6.25. N,N'-(Decane-1,10-Diyl)Bis(3,5-Dimethoxybenzamide) (33e)

Pale white solid, yield 56\%, m.p. $143.4-144.2{ }^{\circ} \mathrm{C} ;{ }^{1} \mathrm{H}-\mathrm{NMR}\left(300 \mathrm{MHz}, \mathrm{CDCl}_{3}+\mathrm{CD}_{3} \mathrm{OD}\right) \delta: 6.79(\mathrm{~d}$, $J=2.1 \mathrm{~Hz}, 4 \mathrm{H}), 6.43(\mathrm{t}, J=1.9 \mathrm{~Hz}, 2 \mathrm{H}), 3.69(\mathrm{~s}, 12 \mathrm{H}), 3.25(\mathrm{t}, J=7.2 \mathrm{~Hz}, 4 \mathrm{H}), 1.50-1.45(\mathrm{~m}, 4 \mathrm{H}), 1.25-1.15$ (m, 12H). ${ }^{13} \mathrm{C}-\mathrm{NMR}\left(101 \mathrm{MHz}, \mathrm{CDCl}_{3}+\mathrm{CD}_{3} \mathrm{OD}\right) \delta:$ 168.01, 160.73, 136.74, 104.94, 103.34, 55.40, 40.03, 29.28, 29.26, 29.11, 26.82. HRMS (ESI) $m / z: 501.2959[\mathrm{M}+\mathrm{H}]^{+}$, calcd. for $\left[\mathrm{C}_{28} \mathrm{H}_{41} \mathrm{~N}_{2} \mathrm{O}_{6}\right]^{+}$501.2965.

4.6.26. N,N'-(Decane-1,10-Diyl)Bis(3,4,5-Trimethoxybenzamide) (34e)

Pale white solid, yield 63\%, m.p. 194-194.9 ${ }^{\circ} \mathrm{C} ;{ }^{1} \mathrm{H}-\mathrm{NMR}\left(300 \mathrm{MHz}, \mathrm{CDCl}_{3}+\mathrm{CD}_{3} \mathrm{OD}\right) \delta: 6.91$ (s, $4 \mathrm{H}), 3.72(\mathrm{~s}, 12 \mathrm{H}), 3.67(\mathrm{~s}, 6 \mathrm{H}), 3.22-3.16(\mathrm{~m}, 4 \mathrm{H}), 1.50-1.36(\mathrm{~m}, 4 \mathrm{H}), 1.22-1.08(\mathrm{~m}, 12 \mathrm{H}) .{ }^{1} \mathrm{H}-\mathrm{NMR}(300$ $\left.\mathrm{MHz}, \mathrm{CDCl}_{3}+\mathrm{CD}_{3} \mathrm{OD}\right) . \delta: 6.91(\mathrm{~s}, 4 \mathrm{H}), 3.72(\mathrm{~s}, 12 \mathrm{H}), 3.67(\mathrm{~s}, 6 \mathrm{H}), 3.22-3.16(\mathrm{~m}, 4 \mathrm{H}), 1.50-1.36(\mathrm{~m}, 4 \mathrm{H})$, 1.22-1.08 (m, 12H). ${ }^{13} \mathrm{C}-\mathrm{NMR}\left(101 \mathrm{MHz}, \mathrm{CDCl}_{3}+\mathrm{CD}_{3} \mathrm{OD}\right) \delta: 167.81,152.77,129.84,104.42,60.53,55.85$, 40.01, 29.17, 29.03, 26.73. HRMS (ESI) $m / z: 561.3169[\mathrm{M}+\mathrm{H}]^{+}$, calcd. for $\left[\mathrm{C}_{30} \mathrm{H}_{45} \mathrm{~N}_{2} \mathrm{O}_{8}\right]^{+}$561.3176.

\subsubsection{7. $\mathrm{N}, \mathrm{N}^{\prime}$-(Decane-1,10-Diyl)Bis(2,3,4-Trimethoxybenzamide) (35e)}

Pale white solid, yield 26\%, m.p. $112.3-112.5^{\circ} \mathrm{C} ;{ }^{1} \mathrm{H}-\mathrm{NMR}\left(300 \mathrm{MHz}, \mathrm{CDCl}_{3}\right) \delta: 7.94(\mathrm{~s}, 2 \mathrm{H}), 7.89$ $(\mathrm{d}, J=8.9 \mathrm{~Hz}, 2 \mathrm{H}), 6.76(\mathrm{~d}, J=9 \mathrm{~Hz}, 2 \mathrm{H}), 3.96(\mathrm{~s}, 6 \mathrm{H}), 3.90(\mathrm{~s}, 6 \mathrm{H}), 3.87(\mathrm{~s}, 6 \mathrm{H}), 3.44(\mathrm{dd}, J=12.7,6.9 \mathrm{~Hz}$, $4 \mathrm{H}), 1.62(\mathrm{dt}, J=14.3,7.1 \mathrm{~Hz}, 4 \mathrm{H}), 1.41-1.29(\mathrm{~m}, 12 \mathrm{H}) .{ }^{13} \mathrm{C}-\mathrm{NMR}\left(101 \mathrm{MHz}, \mathrm{CDCl}_{3}\right) \delta: 164.90,156.35$, $152.42,141.83,126.76,119.31,107.67,61.71,61.08,56.15,39.71,29.78,29.65,29.43,27.24$. HRMS (ESI) $m / z: 561.3172[\mathrm{M}+\mathrm{H}]^{+}$, calcd. for $\left[\mathrm{C}_{30} \mathrm{H}_{45} \mathrm{~N}_{2} \mathrm{O}_{8}\right]^{+} 561.3176$.

\subsection{General Synthetic Procedure for $\mathbf{9 d}, \mathbf{9 f}$}

A mixture of cinnamic acid $(6.30 \mathrm{mmol}), \mathrm{EDCI}(7.50 \mathrm{mmol}), \mathrm{DMAP}(0.60 \mathrm{mmol})$, and anhydrous dichloromethane $(20 \mathrm{~mL})$ was stirred to dissolve, then diamino-alkane $(3 \mathrm{mmol})$ was added and stirred at room temperature for $12 \mathrm{~h}$. The mixture solution was filtered under reduced pressure. After that, the residue was washed with dichloromethane and water successively, and then dried to give a pale white solid. TLC indicated that it was a single point.

\subsection{1. (2E,2'E)-N, $\mathrm{N}^{\prime}$-(Octane-1,8-Diyl)Bis(3-Phenylacrylamide) (9d)}

Pale white solid, yield 63\%, m.p. $186-186.4{ }^{\circ} \mathrm{C} ;{ }^{1} \mathrm{H}-\mathrm{NMR}\left(300 \mathrm{MHz}, \mathrm{CDCl}_{3}+\mathrm{CD}_{3} \mathrm{OD}\right) \delta:$ 7.58-7.29 $(\mathrm{m}, 12 \mathrm{H}), 6.53(\mathrm{~d}, J=15.7 \mathrm{~Hz}, 2 \mathrm{H}), 3.31(\mathrm{t}, J=7.1 \mathrm{~Hz}, 4 \mathrm{H}), 1.59-1.55(\mathrm{~m}, 4 \mathrm{H}), 1.35(\mathrm{~s}, 8 \mathrm{H}) .{ }^{13} \mathrm{C}-\mathrm{NMR}(101$ $\left.\mathrm{MHz}, \mathrm{CDCl}_{3}+\mathrm{CD}_{3} \mathrm{OD}\right) \delta: 166.96,140.39,134.78,129.42,128.59,127.54,120.60,39.43,29.04,28.85,26.57$. HRMS (ESI) $m / z: 405.2537[\mathrm{M}+\mathrm{H}]^{+}$, calcd. for $\left[\mathrm{C}_{26} \mathrm{H}_{33} \mathrm{~N}_{2} \mathrm{O}_{2}\right]^{+} 405.2542$.

\subsection{2. (2E,2'E)-N, $\mathrm{N}^{\prime}$-(Dodecane-1,12-Diyl)Bis(3-Phenylacrylamide) (9f)}

Pale white solid, yield $49 \%$, m.p. $164.7-165^{\circ} \mathrm{C} ;{ }^{1} \mathrm{H}-\mathrm{NMR}\left(300 \mathrm{MHz}, \mathrm{CDCl}_{3}+\mathrm{CD}_{3} \mathrm{OD}\right) \delta: 7.56-7.49$ $(\mathrm{m}, 6 \mathrm{H}), 7.40-7.28(\mathrm{~m}, 6 \mathrm{H}), 6.53(\mathrm{~d}, J=15.7 \mathrm{~Hz}, 2 \mathrm{H}), 3.30(\mathrm{t}, J=7.1 \mathrm{~Hz}, 4 \mathrm{H}), 1.62-1.51(\mathrm{~m}, 4 \mathrm{H}), 1.38-1.23$ (m, 16H). ${ }^{13} \mathrm{C}-\mathrm{NMR}\left(101 \mathrm{MHz}, \mathrm{CDCl}_{3}+\mathrm{CD}_{3} \mathrm{OD}\right) \delta: 166.94,140.22,134.73,129.29,128.47,127.42,120.54$, 39.42, 29.19, 29.03, 28.99, 26.66. HRMS (ESI) $\mathrm{m} / z$ : $461.3166[\mathrm{M}+\mathrm{H}]^{+}$, calcd. for $\left[\mathrm{C}_{30} \mathrm{H}_{41} \mathrm{~N}_{2} \mathrm{O}_{2}\right]^{+} 461.3168$.

\subsection{General Synthetic Procedure for $\mathbf{9 g}-\mathbf{9 i}$}

A mixture of cinnamic acid $(6.30 \mathrm{mmol}), \mathrm{EDCI}(7.50 \mathrm{mmol}), \mathrm{DMAP}(0.60 \mathrm{mmol})$, and anhydrous dichloromethane $(20 \mathrm{~mL})$ was stirred to dissolve, then alkane-diol $(3 \mathrm{mmol})$ was added and stirred at room temperature for $12 \mathrm{~h}$. The mixture solution was filtered under reduced pressure. After that, the residue was washed with dichloromethane and water successively, subsequently, purified by preparative TLC eluted with petroleum ether/ethyl acetate $=5: 1$ to give pale white solid. 


\subsubsection{Octane-1,8-Diyl (2E,2'E)-Bis(3-Phenylacrylate) (9g)}

Pale white solid, yield 35\%, m.p. 61.1-62.5 ${ }^{\circ} \mathrm{C} ;{ }^{1} \mathrm{H}-\mathrm{NMR}\left(300 \mathrm{MHz}, \mathrm{CDCl}_{3}\right) \delta: 7.68(\mathrm{~d}, J=16 \mathrm{~Hz}$, 2H), 7.58-7.46 (m, 4H), 7.43-7.30 (m, 6H), $6.45(\mathrm{~d}, J=16 \mathrm{~Hz}, 2 \mathrm{H}), 4.21(\mathrm{t}, J=6.7 \mathrm{~Hz}, 4 \mathrm{H}), 1.77-1.68(\mathrm{~m}$, $4 \mathrm{H}), 1.46-1.40(\mathrm{~m}, 8 \mathrm{H}) .{ }^{13} \mathrm{C}-\mathrm{NMR}\left(101 \mathrm{MHz}, \mathrm{CDCl}_{3}\right) \delta: 167.22,144.72,134.62,130.35,129.01,128.19$, $118.43,64.79,29.31,28.85,26.05$. HRMS (ESI) $m / z: 407.2223[\mathrm{M}+\mathrm{H}]^{+}$, calcd. for $\left[\mathrm{C}_{26} \mathrm{H}_{31} \mathrm{O}_{4}\right]^{+} 407.2222$.

\subsubsection{Decane-1,10-Diyl (2E,2'E)-Bis(3-Phenylacrylate) (9h)}

Pale white solid, yield 33\%, m.p. 118.6-119.2 ${ }^{\circ} \mathrm{C} ;{ }^{1} \mathrm{H}-\mathrm{NMR}\left(300 \mathrm{MHz}, \mathrm{CDCl}_{3}\right) \delta: 7.68(\mathrm{~d}, J=16 \mathrm{~Hz}$, $2 \mathrm{H}), 7.57-7.48(\mathrm{~m}, 4 \mathrm{H}), 7.38(\mathrm{dd}, J=6.6,3.6 \mathrm{~Hz}, 6 \mathrm{H}), 6.45(\mathrm{~d}, J=16 \mathrm{~Hz}, 2 \mathrm{H}), 4.21(\mathrm{t}, J=6.7 \mathrm{~Hz}, 4 \mathrm{H})$, 1.77-1.62 (m, 4H), 1.48-1.25 (m, 12H). ${ }^{13} \mathrm{C}-\mathrm{NMR}\left(101 \mathrm{MHz}, \mathrm{CDCl}_{3}\right) \delta:$ 167.23, 144.69, 134.64, 130.35, $129.01,128.19,118.46,64.85,29.58,29.40,28.88,26.12$. HRMS (ESI) $m / z: 435.2534[\mathrm{M}+\mathrm{H}]^{+}$, calcd. for $\left[\mathrm{C}_{28} \mathrm{H}_{35} \mathrm{O}_{4}\right]^{+} 435.2535$.

\subsubsection{Dodecane-1,12-Diyl (2E,2'E)-Bis(3-Phenylacrylate) (9i)}

Pale white solid, yield 28\%, m.p. 63.1-64 ${ }^{\circ} \mathrm{C} ;{ }^{1} \mathrm{H}-\mathrm{NMR}\left(300 \mathrm{MHz}, \mathrm{CDCl}_{3}\right) \delta: 7.68(\mathrm{~d}, J=16 \mathrm{~Hz}$, $2 \mathrm{H}), 7.52(\mathrm{dt}, J=4.6,3.2 \mathrm{~Hz}, 4 \mathrm{H}), 7.42-7.33(\mathrm{~m}, 6 \mathrm{H}), 6.45(\mathrm{~d}, J=16 \mathrm{~Hz}, 2 \mathrm{H}), 4.21(\mathrm{t}, J=6.7 \mathrm{~Hz}, 4 \mathrm{H})$, 1.77-1.65 (m, 4H), 1.43-1.25 (m, 16H). ${ }^{13} \mathrm{C}-\mathrm{NMR}\left(101 \mathrm{MHz}, \mathrm{CDCl}_{3}\right) \delta:$ 167.22, 144.68, 134.64, 130.34, $129.01,128.18,118.47,64.87,29.68,29.66,29.42,28.87,26.12$. HRMS (ESI) $m / z: 463.2851[\mathrm{M}+\mathrm{H}]^{+}$, calcd. for $\left[\mathrm{C}_{30} \mathrm{H}_{39} \mathrm{O}_{4}\right]^{+} 463.2828$.

\subsection{General Synthetic Procedure for $\mathbf{9 j - 9 m}$}

A mixture of cinnamic acid $(6.30 \mathrm{mmol}), \mathrm{EDCI}(7.50 \mathrm{mmol}), \mathrm{DMAP}(0.60 \mathrm{mmol})$, and anhydrous dichloromethane $(20 \mathrm{~mL})$ was stirred to dissolve, then diamino-ether $(3 \mathrm{mmol})$ was added and stirred at room temperature for $12 \mathrm{~h}$. Then, the solid was filtered off, the filtrate was added with $\mathrm{H}_{2} \mathrm{O}(50 \mathrm{~mL})$ and extracted by dichloromethane three times. The combined organic layers were washed with $\mathrm{H}_{2} \mathrm{O}$ and brine, dried with anhydrous sodium sulfate for $8 \mathrm{~h}$, filtered, and evaporated. The resulting residue was purified by preparative TLC with petroleum ether/ethyl acetate $=2: 1-1: 1$ to give pale white solid or light yellow oil.

\subsection{1. (2E,2'E)-N,N'-((Ethane-1,2-Diylbis(Oxy))Bis(Ethane-2,1-Diyl))Bis(3-Phenylacrylamide) (9j)}

Pale white solid, yield 78\%, m.p. 117.9-118.5 ${ }^{\circ} \mathrm{C} ;{ }^{1} \mathrm{H}-\mathrm{NMR}\left(300 \mathrm{MHz}, \mathrm{CDCl}_{3}\right) \delta: 7.62(\mathrm{~d}, J=15.6$ $\mathrm{Hz}, 2 \mathrm{H}), 7.51-7.41(\mathrm{~m}, 4 \mathrm{H}), 7.37-7.27(\mathrm{~m}, 6 \mathrm{H}), 6.48(\mathrm{~d}, J=15.6 \mathrm{~Hz}, 2 \mathrm{H}), 3.65-3.60(\mathrm{~m}, 12 \mathrm{H}) .{ }^{13} \mathrm{C}-\mathrm{NMR}$ $\left(101 \mathrm{MHz}, \mathrm{CDCl}_{3}\right) \delta: 166.26,141.19,134.95,129.77,128.92,127.92,120.82,70.50,70.05,39.63$. HRMS (ESI) $m / z: 409.2121[\mathrm{M}+\mathrm{H}]^{+}$, calcd. for $\left[\mathrm{C}_{24} \mathrm{H}_{29} \mathrm{~N}_{2} \mathrm{O}_{4}\right]^{+} 409.2127$.

4.9.2.

(2E,2'E)-N,N'-(((Oxybis(Ethane-2,1-Diyl))Bis(Oxy))Bis(Ethane-2,1-Diyl))Bis(3-Phenylacrylamide) (9k)

Light yellow oil, yield 28\%; ${ }^{1} \mathrm{H}-\mathrm{NMR}\left(300 \mathrm{MHz}, \mathrm{CDCl}_{3}\right) \delta: 7.60(\mathrm{~d}, J=15.6 \mathrm{~Hz}, 2 \mathrm{H}), 7.45(\mathrm{dd}, J$ $=6.5,3.1 \mathrm{~Hz}, 4 \mathrm{H}), 7.32-7.30(\mathrm{~m}, 4 \mathrm{H}), 6.71(\mathrm{t}, J=5.7 \mathrm{~Hz}, 2 \mathrm{H}), 6.47(\mathrm{~d}, J=15.6 \mathrm{~Hz}, 2 \mathrm{H}), 3.65(\mathrm{~s}, 8 \mathrm{H})$, 3.63-3.54 (m, 8H). ${ }^{13} \mathrm{C}-\mathrm{NMR}\left(101 \mathrm{MHz}, \mathrm{CDCl}_{3}\right) \delta: 166.17,140.96,134.98,129.70,128.89,127.86,120.93$, 70.49, 70.27, 70, 39.59. HRMS (ESI) $m / z: 453.2387[\mathrm{M}+\mathrm{H}]^{+}$, calcd. for $\left[\mathrm{C}_{26} \mathrm{H}_{33} \mathrm{~N}_{2} \mathrm{O}_{5}\right]^{+} 453.2389$.

\subsection{3. (Ethane-1,2-Diylbis(Oxy))Bis(Ethane-2,1-Diyl) (2E,2'E)-Bis(3-Phenylacrylate) (91)}

Light yellow oil, yield $65 \%$; ${ }^{1} \mathrm{H}-\mathrm{NMR}\left(300 \mathrm{MHz}, \mathrm{CDCl}_{3}\right) \delta: 7.70(\mathrm{~d}, J=16 \mathrm{~Hz}, 2 \mathrm{H}), 7.54-7.48$ $(\mathrm{m}, 4 \mathrm{H}), 7.40-7.34(\mathrm{~m}, 6 \mathrm{H}), 6.48(\mathrm{~d}, J=16 \mathrm{~Hz}, 2 \mathrm{H}), 4.42-4.36(\mathrm{~m}, 4 \mathrm{H}), 3.84-3.77(\mathrm{~m}, 4 \mathrm{H}), 3.73(\mathrm{~s}, 4 \mathrm{H})$. ${ }^{13} \mathrm{C}-\mathrm{NMR}\left(101 \mathrm{MHz}, \mathrm{CDCl}_{3}\right.$ ) $\delta:$ 167.03, 145.21, 134.50, 130.44, 129.01, 128.23, 118, 70.79, 69.48, 63.78. HRMS (ESI) $m / z: 411.1805[\mathrm{M}+\mathrm{H}]^{+}$, calcd. for $\left[\mathrm{C}_{24} \mathrm{H}_{27} \mathrm{O}_{6}\right]^{+} 411.1808$. 


\subsection{4. ((Oxybis(Ethane-2,1-Diyl))Bis(Oxy))Bis(Ethane-2,1-Diyl) (2E,2'E)-bis(3-Phenylacrylate) (9m)}

Light yellow oil, yield 87\%; ${ }^{1} \mathrm{H}-\mathrm{NMR}\left(300 \mathrm{MHz}, \mathrm{CDCl}_{3}\right) \delta: 7.70(\mathrm{~d}, J=16 \mathrm{~Hz}, 2 \mathrm{H}), 7.55-7.48(\mathrm{~m}$, $4 \mathrm{H}), 7.38(\mathrm{dd}, J=3.8,2.7 \mathrm{~Hz}, 6 \mathrm{H}), 6.48(\mathrm{~d}, J=16 \mathrm{~Hz}, 2 \mathrm{H}), 4.37(\mathrm{dd}, J=5.5,4.1 \mathrm{~Hz}, 4 \mathrm{H}), 3.81-3.74(\mathrm{~m}$, $4 \mathrm{H}), 3.70$ (s, 8H). ${ }^{13} \mathrm{C}-\mathrm{NMR}\left(101 \mathrm{MHz}, \mathrm{CDCl}_{3}\right) \delta: 167.03,145.19,134.52,130.45,129.02,128.23,118.04$, 77.48, 77.36, 77.16, 76.84, 70.82, 70.79, 69.42, 63.80. HRMS (ESI) $m / z: 472.2337\left[\mathrm{M}+\mathrm{NH}_{4}\right]^{+}$, calcd. for $\left[\mathrm{C}_{26} \mathrm{H}_{34} \mathrm{NO}_{7}\right]^{+} 472.2335$.

\subsection{Biological Assays}

\subsubsection{Cell Culture}

The tested cells were obtained from Shanghai Institute of Biochemistry and Cell Biology of the Chinese Academy of Sciences (Shanghai, China). HeLa and Hep G2 cell lines were cultured in Dulbecco's modified Eagle's medium (DMEM; gibco, Life Technologies, Carlsbad, CA, USA) supplemented with 10\% fetal bovine serum (FBS; Biological Industries), $100 \mathrm{U} / \mathrm{mL}$ penicillin-streptomycin (PS; gibco, Life Technologies, Carlsbad, CA, USA). MCF-7 and A549 cell lines were maintained in RPMI-1640 media (gibco, Life Technologies, Carlsbad, CA, USA) supplemented with 10\% FBS and 100 U/mL PS. FaDu cell lines were cultured in minimum essential medium (MEM; Gibco, Life Technologies, Carlsbad, CA, USA) supplemented with 10\% FBS and 100 U/mL PS. MCF 10A cell lines were maintained in Mammary MEGM kit (Lonza/Clonetics) supplemented with $100 \mathrm{ng} / \mathrm{mL}$ cholera toxin (Sigma, Shanghai, China). Cell lines were grown at $37^{\circ} \mathrm{C}$ in a humidified atmosphere of $5 \% \mathrm{CO}_{2}$.

\subsubsection{Cell Viability Assay}

The growth-inhibitory effects against HeLa, Hep G2, MCF-7, FaDu, and A549 cancer cells and normal cell lines MCF 10A were determined by MTT assay [21]. All of the synthesized compounds and the positive control drug doxorubicin were dissolved in $0.1 \%$ DMSO. Cells were seeded in 96 well plates at a density of $1 \times 10^{4}$ cells per well and incubated for $24 \mathrm{~h}$ at $37^{\circ} \mathrm{C}$ in a humidified atmosphere of $5 \% \mathrm{CO}_{2}$. The cells were then incubated with various concentrations of drugs for $48 \mathrm{~h}$ in a $5 \% \mathrm{CO}_{2}$ incubator at $37^{\circ} \mathrm{C}$. After treatment with $1 \mathrm{mg} / \mathrm{mL}$ 3-(4,5-dimethylthiazol-2-yl)-2,5-diphenyltetrazolium bromide (MTT) solution for $4 \mathrm{~h}$, the formazan crystals were dissolved in $100 \mu \mathrm{L}$ DMSO in each well. Plates were read on a microplate reader (Thermo Varioskan Flash 3001) at $490 \mathrm{~nm}$. The experiment was performed in triplicate. The inhibitory concentration at $50 \%\left(\mathrm{IC}_{50}\right)$ was calculated based on concentration-inhibition relationships via regression using SPSS software (Version 17.0).

\subsubsection{Colony Formation Assay}

FaDu cells were seeded in a 6-well plate with 500 cells per well and incubated for $24 \mathrm{~h}$. Then, the cells were treated with compound $8 \mathbf{e}$ at various final concentrations of $0,0.75,1.50,3 \mathrm{nM}$. Following treatment for 10 days, the cells were washed with PBS twice and fixed with $4 \%$ paraformaldehyde for $10 \mathrm{~min}$ at room temperature. Then, the cell colonies were visualized by staining with $0.1 \%$ crystal violet for $10 \mathrm{~min}$. The image was photographed with Handy camera, and the numbers of cell colonies were analyzed using the open Image J software (Developed by National Institutes of Health). A group of $>50$ cells was defined as one colony. Triplicate wells were set up for each concentration.

\subsubsection{Live/Dead Staining}

The Calcein AM/propidium iodide (PI) double staining was performed following the manufacturer's instructions (Dojindo Laboratory, Kumamoto, Japan). Briefly, FaDu cells were seeded in 6-well plates overnight. Then, the $8 \mathbf{e}$ solutions at final concentrations of $2.5 \mathrm{nM}, 5 \mathrm{nM}$, and 10 $\mathrm{nM}$ were added. After incubation for $24 \mathrm{~h}$, the cells were collected, washed with PBS, and stained by a mixture of $2 \mu \mathrm{M}$ Calcein-AM (live cells, green) and $4.5 \mu \mathrm{M}$ PI (dead cells, red) solution in the dark for $30 \mathrm{~min}$ at $37^{\circ} \mathrm{C}$ (excitation $490 \mathrm{~nm}$ ). Then, the cells were rinsed with PBS twice and re-suspended in the 
cell medium. Confocal fluorescence images were acquired using a laser scanning confocal microscope (LSCM, Carl-Zeiss LSM 710).

\subsubsection{Hoechst 33,342 Staining}

For Hoechst staining, FaDu cells were seeded onto a glass-bottom of cell culture dish at a density of $1 \times 10^{5}$ cells. After incubation for $24 \mathrm{~h}$, the media containing $20 \mathrm{nM}$ of the compound $8 \mathrm{e}$ was used to replace the culture medium. Then, the cells were stained with Hoechst 33,342 solution $(10 \mu \mathrm{g} / \mathrm{mL}$ in the culture medium, Beyotime Institute of Biotechnology, Shanghai, China) at $37^{\circ} \mathrm{C}$ in the dark for $20 \mathrm{~min}$ after treatment with $\mathbf{8 e}$. Then, the cells were washed with the serum-free medium to remove excess dye. LSCM (Carl-Zeiss LSM 710) was used to capture the images of nuclear morphological changes to find apoptotic cells.

\subsubsection{Flow Cytometric Analysis of Apoptosis by Annexin V-FITC/PI Staining}

Apoptosis in FaDu cells was evaluated by an annexin V-FITC/PI apoptosis detection kit (Beyotime Institute of Biotechnology, Shanghai, China). Briefly, FaDu cells were treated with various concentrations of compound $8 \mathbf{e}(2,5,10 \mathrm{nM})$ or DMSO as vehicle control for $24 \mathrm{~h}$ at $37^{\circ} \mathrm{C}$; then, the cells were washed twice with cold $1 \times$ PBS and centrifuged at $1000 \mathrm{rpm}$ for $5 \mathrm{~min}$. The harvested cells were resuspended gently in $400 \mu \mathrm{L}$ binding buffer, containing $5 \mu \mathrm{L}$ annexin V-FITC and $10 \mu \mathrm{L}$ PI. After incubating for 15 $\mathrm{min}$ in the dark at room temperature, the cells were analyzed with flow cytometry (CyFlow ${ }^{\circledR}$ Cube 6 , Sysmex). Data were shown as pseudo color graphs and analyzed using FlowJo Software (Tree Star Inc, Ashland, OR).

\subsubsection{Mitochondrial Membrane Potential $(\Delta \Psi \mathrm{m})$ Analysis}

The mitochondrial membrane potential $(\Delta \Psi \mathrm{m})$ was detected by a mitochondrial membrane potential assay kit with JC-1 (Beyotime Institute of Biotechnology, Shanghai, China). Briefly, after treatment with various concentrations of compound $8 \mathbf{e}(2,5,10 \mathrm{nM})$ for $24 \mathrm{~h}$, FaDu cells were harvested and stained with $500 \mu \mathrm{L} 1 \times \mathrm{JC}-1$ dye solution at $37^{\circ} \mathrm{C}$ for $20 \mathrm{~min}$ in the dark. Then, the treated cells were washed twice and resuspended by $1 \times \mathrm{JC}-1$ staining buffer. The fluorescence of approximately $1 \times 10^{4}$ cells was analyzed using flow cytometry $\left(\mathrm{CyFlow}^{\circledR}\right.$ Cube 6, Sysmex).

\subsubsection{Cell Cycle Analysis}

The cell cycle analysis was carried out by a cell cycle and apoptosis analysis kit with a propidium iodide (PI) staining method (Beyotime Institute of Biotechnology, Shanghai, China). Briefly, FaDu cells were incubated with the above-mentioned doses of compound $8 \mathbf{e}$ for $24 \mathrm{~h}$; all samples were collected, washed once with cold $1 \times$ PBS, and fixed by $70 \%$ ice-cold ethanol at $4{ }^{\circ} \mathrm{C}$ for $12 \mathrm{~h}$. Then, the fixed cells were washed once with cold $1 \times$ PBS and stained with $500 \mu \mathrm{L} 1 \times$ PI dye solution (containing $10 \mu \mathrm{L}$ RNase A) at $37^{\circ} \mathrm{C}$ for $30 \mathrm{~min}$ in the dark. The red fluorescence was detected using a flow cytometer (CyFlow ${ }^{\circledR}$ Cube 6, Sysmex). The data were analyzed using FlowJo Software (Tree Star Inc, Ashland, OR, USA).

\subsubsection{In Silico ADMET Prediction}

A computational study of all synthesized compounds was carried out for the prediction of ADMET (absorption, distribution, metabolism, excretion, and toxicity) properties. In this module, thirteen mathematical models, such as HBD (hydrogen bond donor), HBA (hydrogen bond acceptor), RBN (number of rotatable bonds), $\log \mathrm{P}$ ( $\log$ of the octanol/water partition coefficient), $\log \mathrm{S}(\log$ of the aqueous solubility), and PSA (polar surface area) were predicted via Discovery Studio 2.0 Software (Studio 2.5, Accelrys, Co. Ltd., San Diego, CA, USA) and HIA (human intestinal absorption), PPB (plasma protein binding), CYP3D4 (CYP3D4 inhibition), $\mathrm{T}_{1 / 2}$ (half lifetime), HT (human hepatotoxicity), and $\mathrm{LD}_{50}$ (median lethal dose) were calculated using web-based applications and then analyzed to 
predict the drug likeliness profile (Xiangya School of Pharmaceutical Sciences and Central South University, http://admet.scbdd.com/home/index/) [28]. We also screened our novel derivatives through the prediction model by Egan et al. [29,30]. Two molecular descriptors, AlogP98 and PSA, were computed and plotted in a 2D plane to comprehensively evaluate the absorption and blood-brain penetration of the compounds.

Supplementary Materials: The following are available online at http://www.mdpi.com/1420-3049/24/24/4505/s1, ${ }^{1} \mathrm{H}-\mathrm{NMR},{ }^{13} \mathrm{C}-\mathrm{NMR}$ and HR-MS spectra of compounds.

Author Contributions: Ideas and experiment design: J.W., G.H., and T.L.; Chemistry and Biology: J.W., G.H., G.L., and W.W.; Analysis and interpretation of data: J.W., G.H., G.L., and W.W.; Writing and review of the manuscript: J.W., G.H., G.L., W.W., and T.L.; Study supervision: T.L. and G.H.

Funding: This research was funded by the national major science and technology special project for "significant new drugs development" (2018ZX09711001-005-018), "the medical and health science and technology innovation project of Chinese Academy of Medical Science" (2017-I2M-3-021/2019-I2M-1-005), "the Tianjin special support program for talent development" (TJTZJH-GCCCXCYTD-1-30).

Acknowledgments: The authors gratefully acknowledge the Institute of Materia Medica, Chinese Academy of Medical Sciences and Peking Union Medical College and information technology center for affording the Discovery Studio 2.0 Software.

Conflicts of Interest: The authors declare that they have no competing interests.

\section{References}

1. Cragg, G.M.; Newman, D.J. Natural products: A continuing source of novel drug leads. Biochim. Et Biophys. Acta (Bba) - Gen. Subj. 2013, 1830, 3670-3695. [CrossRef] [PubMed]

2. Chang, C.-Y.; Kao, T.-K.; Chen, W.-Y.; Ou, Y.-C.; Li, J.-R.; Liao, S.-L.; Raung, S.-L.; Chen, C.-J. Tetramethylpyrazine inhibits neutrophil activation following permanent cerebral ischemia in rats. Biochem. Biophys. Res. Commun. 2015, 463, 421-427. [CrossRef] [PubMed]

3. Cao, J.; Miao, Q.; Miao, S.; Bi, L.; Zhang, S.; Yang, Q.; Zhou, X.; Zhang, M.; Xie, Y.; Zhang, J.; et al. Tetramethylpyrazine (TMP) exerts antitumor effects by inducing apoptosis and autophagy in hepatocellular carcinoma. Int. Immunopharmacol. 2015, 26, 212-220. [CrossRef] [PubMed]

4. Bi, L.; Yan, X.; Chen, W.; Gao, J.; Qian, L.; Qiu, S. Antihepatocellular Carcinoma Potential of Tetramethylpyrazine Induces Cell Cycle Modulation and Mitochondrial-Dependent Apoptosis: Regulation of p53 Signaling Pathway in HepG2 Cells In Vitro. Integr. Cancer Ther. 2016, 15, 226-236. [CrossRef]

5. Ai, Y.; Zhu, B.; Ren, C.; Kang, F.; Li, J.; Huang, Z.; Lai, Y.; Peng, S.; Ding, K.; Tian, J.; et al. Discovery of New Monocarbonyl Ligustrazine-Curcumin Hybrids for Intervention of Drug-Sensitive and Drug-Resistant Lung Cancer. J. Med. Chem. 2016, 59, 1747-1760. [CrossRef]

6. Xu, B.; Yan, W.-Q.; Xu, X.; Wu, G.-R.; Zhang, C.-Z.; Han, Y.-T.; Chu, F.-H.; Zhao, R.; Wang, P.-L.; Lei, H.-M. Combination of amino acid/dipeptide with ligustrazine-betulinic acid as antitumor agents. Eur. J. Med. Chem. 2017, 130, 26-38. [CrossRef]

7. Wang, P.-L.; Cheng, Y.-T.; Xu, K.; An, Y.-W.; Wang, W.; Li, Q.-S.; Han, Q.-J; Li, Q.; Zhang, H.-G.; Lei, H.-M. Synthesis and Antitumor Evaluation of One Novel Tetramethylpyrazine-Rhein Derivative. Asian J. Chem. 2013, 25, 4885-4888. [CrossRef]

8. Chow, L.M.C.; Chan, T.H. Novel Classes of Dimer Antitumour Drug Candidates. Curr. Pharm. Des. 2009, 15, 659-674. [CrossRef]

9. Joshi, A.; Vance, D.; Rai, P.; Thiyagarajan, A.; Kane, R.S. The Design of Polyvalent Therapeutics. Chem. -A Eur. J. 2008, 14, 7738-7747. [CrossRef]

10. Beekman, A.C.; Barentsen, A.R.W.; Woerdenbag, H.J.; Van Uden, W.; Pras, N.; Konings, A.W.T.; El-Feraly, F.S.; Galal, A.M.; Wikström, H.V. Stereochemistry-Dependent Cytotoxicity of Some Artemisinin Derivatives. J. Nat. Prod. 1997, 60, 325-330. [CrossRef]

11. Hu, Y.; Li, C.; Kulkarni, B.A.; Strobel, G.; Lobkovsky, E.; Torczynski, R.M.; Porco, J.A. Exploring Chemical Diversity of Epoxyquinoid Natural Products: Synthesis and Biological Activity of (-)-Jesterone and Related Molecules. Org. Lett. 2001, 3, 1649-1652. [CrossRef] [PubMed]

12. Verhoeven, D.T.; Goldbohm, R.A.; van Poppel, G.; Verhagen, H.; van den Brandt, P.A. Epidemiological studies on brassica vegetables and cancer risk. Cancer Epidemiol. Biomark. Amp; Prev. 1996, 5, 733-748. 
13. Chaires, J.B.; Leng, F.; Przewloka, T.; Fokt, I.; Ling, Y.H.; Perezsoler, R.; Priebe, W. Structure-based design of a new bisintercalating anthracycline antibiotic. J. Med. Chem. 1997, 40, 261-266. [CrossRef] [PubMed]

14. Zha, G.-F.; Qin, H.-L.; Youssif, B.G.M.; Amjad, M.W.; Raja, M.A.G.; Abdelazeem, A.H.; Bukhari, S.N.A. Discovery of potential anticancer multi-targeted ligustrazine based cyclohexanone and oxime analogs overcoming the cancer multidrug resistance. Eur. J. Med. Chem. 2017, 135, 34-48. [CrossRef]

15. Wang, P.; She, G.; Yang, Y.; Li, Q.; Zhang, H.; Liu, J.; Cao, Y.; Xu, X.; Lei, H. Synthesis and Biological Evaluation of New Ligustrazine Derivatives as Anti-Tumor Agents. Molecules 2012, 17, 4972-4985. [CrossRef]

16. Xu, B.; Chu, F.; Zhang, Y.; Wang, X.; Li, Q.; Liu, W.; Xu, X.; Xing, Y.; Chen, J.; Wang, P.; et al. A Series of New Ligustrazine-Triterpenes Derivatives as Anti-Tumor Agents: Design, Synthesis, and Biological Evaluation. Int. J. Mol. Sci. 2015, 16, 21035-21055. [CrossRef]

17. Taylor, A.P.; Robinson, R.P.; Fobian, Y.M.; Blakemore, D.C.; Jones, L.H.; Fadeyi, O. Modern advances in heterocyclic chemistry in drug discovery. Org. Biomol. Chem. 2016, 14, 6611-6637. [CrossRef]

18. Klein, B.; Berkowitz, J. Pyrazines. I. Pyrazine-N-oxides. Preparation and Spectral Characteristics1. J. Am. Chem. Soc. 1959, 81, 5160-5166. [CrossRef]

19. Cheng, X.-C.; Liu, X.-Y.; Xu, W.-F.; Guo, X.-L.; Zhang, N.; Song, Y.-N. Ligustrazine derivatives. Part 3: Design, synthesis and evaluation of novel acylpiperazinyl derivatives as potential cerebrocardiac vascular agents. Bioorganic Med. Chem. 2009, 17, 3018-3024. [CrossRef]

20. Wu, G.-R.; Xu, B.; Yang, Y.-Q.; Zhang, X.-Y.; Fang, K.; Ma, T.; Wang, H.; Xue, N.-N.; Chen, M.; Guo, W.-B.; et al. Synthesis and biological evaluation of podophyllotoxin derivatives as selective antitumor agents. Eur. J. Med. Chem. 2018, 155, 183-196. [CrossRef]

21. van Meerloo, J.; Kaspers, G.J.L.; Cloos, J. Cell Sensitivity Assays: The MTT Assay. In Cancer Cell Culture: Methods and Protocols; Cree, I.A., Ed.; Humana Press: Totowa, NJ, USA, 2011; pp. 237-245.

22. Yi, B.; Liu, D.; He, M.; Li, Q.; Liu, T.; Shao, J. Role of the ROS/AMPK signaling pathway in tetramethylpyrazine-induced apoptosis in gastric cancer cells. Oncol. Lett. 2013, 6, 583-589. [CrossRef] [PubMed]

23. Shen, J.; Zeng, L.; Pan, L.; Yuan, S.; Wu, M.; Kong, X. Tetramethylpyrazine regulates breast cancer cell viability, migration, invasion and apoptosis by affecting the activity of Akt and caspase-3. Oncol. Lett. 2018, 15, 4557-4563. [CrossRef] [PubMed]

24. Chu, F.; Xu, X.; Li, G.; Gu, S.; Xu, K.; Gong, Y.; Xu, B.; Wang, M.; Zhang, H.; Zhang, Y.; et al. Amino acid derivatives of ligustrazine-oleanolic acid as new cytotoxic agents. Molecules 2014, 19, 18215-18231. [CrossRef] [PubMed]

25. Song, F.; Zhang, L.; Yu, H.-X.; Lu, R.-R.; Bao, J.-D.; Tan, C.; Sun, Z. The mechanism underlying proliferation-inhibitory and apoptosis-inducing effects of curcumin on papillary thyroid cancer cells. Food Chem. 2012, 132, 43-50. [CrossRef] [PubMed]

26. Lipinski, C.A.; Lombardo, F.; Dominy, B.W.; Feeney, P.J. Experimental and computational approaches to estimate solubility and permeability in drug discovery and development settings. Adv. Drug Deliv. Rev. 2012, 64, 4-17. [CrossRef]

27. Meena, A.; Yadav, D.K.; Srivastava, A.; Khan, F.; Chanda, D.; Chattopadhyay, S.K. In Silico Exploration of Anti-Inflammatory Activity of Natural Coumarinolignoids. Chem. Biol. Drug Des. 2011, 78, 567-579. [CrossRef]

28. Dong, J.; Wang, N.-N.; Yao, Z.-J.; Zhang, L.; Cheng, Y.; Ouyang, D.; Lu, A.-P.; Cao, D.-S. ADMETlab: A platform for systematic ADMET evaluation based on a comprehensively collected ADMET database. J. Cheminformatics 2018, 10, 29. [CrossRef]

29. Egan, W.J.; Lauri, G. Prediction of intestinal permeability. Adv. Drug Deliv. Rev. 2002, 54, 273-289. [CrossRef]

30. Egan, W.J.; Merz, K.M.; Baldwin, J.J. Prediction of Drug Absorption Using Multivariate Statistics. J. Med. Chem. 2000, 43, 3867-3877. [CrossRef]

Sample Availability: Samples of all compounds are available from the authors.

(C) 2019 by the authors. Licensee MDPI, Basel, Switzerland. This article is an open access article distributed under the terms and conditions of the Creative Commons Attribution (CC BY) license (http://creativecommons.org/licenses/by/4.0/). 